\title{
Disentangling interactions between microbial communities and roots in deep subsoil
}

Martina I. Gocke ${ }^{a, 1, *}$, Arnaud Huguet ${ }^{b}$, Sylvie Derenne ${ }^{b}$, Steffen Kolbc, Michaela A. Dippold ${ }^{d}$,

Guido L.B. Wiesenberga

aDepartment of Geography, University of Zurich, Winterthurerstrasse 190, 8057 Zürich, Switzerland; mgocke@uni-bonn.de (M.I. Gocke), guido.wiesenberg@geo.uzh.ch (G.L.B. Wiesenberg)

bSorbonne Universités, UPMC Univ Paris 06, UMR 7619, METIS, 75005 Paris, France;

arnaud.huguet@upmc.fr (A. Huguet), sylvie.derenne@upmc.fr (S. Derenne)

'Leibniz Center for Agricultural Landscape Research, Landscape Biogeochemistry, Eberswalder

Straße 84, 15374 Münchberg, Germany; steffen.kolb@zalf.de (S. Kolb)

dDepartment of Agricultural Soil Science, University of Göttingen, Büsgenweg 2, 37077 Göttingen,

Germany; dippold@gwdg.de (M.A. Dippold)

${ }^{1}$ Present Address: Institute of Crop Science and Resource Conservation, University of Bonn,

Nussallee 13, 53115 Bonn, Germany

${ }^{*}$ Corresponding author, phone $+49-228-7368748$ 


\section{$\underline{\text { Abstract }}$}

Soils, paleosols and terrestrial sediments serve as archives for studying climate change, and represent important terrestrial carbon pools. Archive functioning relies on the chronological integrity of the respective units. Incorporation of younger organic matter (OM) e.g. by plant roots and associated microorganisms into deep subsoil and underlying soil parent material may reduce reliability of paleoenvironmental records and stability of buried OM. Long-term effects of sedimentary characteristics and deep rooting on deep subsoil microbial communities remain largely unknown. We characterized fossil and living microbial communities based on molecular markers in a Central European Late Pleistocene loess-paleosol sequence containing recent and ancient roots with ages of several millenia. The molecular approach, comprising free and phospholipid fatty acids (FAs), core and intact polar glycerol dialkyl glycerol tetraethers (GDGTs), as well as 16S rRNA genes from bacterial DNA, revealed the presence of living microorganisms along the sequence, with bacterial community composition comparable to that of modern topsoils. Up to $88 \%$ redundancy between bacterial genetic fingerprint and molecular signature of fossil microorganisms suggested a timeintegrated signal of the molecular markers accumulated over a time span potentially lasting from sedimentation over one or more rooting phases until today. Free FAs, core GDGTs and DNA, considered as remains of fossil microorganisms, corresponded with ancient and recent root quantities, whereas phospholipid FAs and intact polar GDGTs, presumably derived from living microorganisms, correlated only with living roots. The biogeochemical and ecological disequilibrium induced by postsedimentary rooting may entail long-term microbial processes like OM mineralization, which may continue even millenia after the lifetime of the root. Deep roots and their fossil remains have been observed in various terrestrial settings, and roots as well as associated microorganisms cause both, OM incorporation and mineralization. Therefore, these findings are crucial for improved understanding of OM dynamics and carbon sequestration potential in deep subsoils.

\section{Key words}

biopore, microbial hotspot, molecular marker, paleoenvironmental archive, rhizosphere, terrestrial sediment 


\section{Introduction}

The existence of microbial life in deeper parts of the unsaturated subsurface like e.g. in terrestrial sediments is well known (Holden and Fierer, 2005). Hotspots in the deep subsoil >> $1 \mathrm{~m}$ depth including soil parent material stimulating microbial thriving are e.g. paleosols (Brockman et al., 1992) or places of preferential flow with accumulated dissolved organic carbon ( $\mathrm{C}_{\text {org }}$; Bundt et al., 2001). In addition, deep roots entering the sediment during and after its deposition may provide such places of preferential water flow as well as Corg and nutrient accumulation (Kautz et al., 2013), as demonstrated by the positive correlation of Corg contents and root biomass distribution (Wang et al., 2010). The rhizosphere as potential microbial hotspot, however, has been largely ignored below $0.5 \mathrm{~m}$ depth, although the ability of roots to penetrate subsoil and underlying soil parent material to several meter depth is known for various plant groups (Canadell et al., 1996). Deep roots have been studied in various soils and unconsolidated terrestrial sediments including loess-(paleo)soil and sand-(paleo)soil sequences in Central and Southeast Europe (Gocke et al., 2014a, 2014b, 2015), where they were observed to occur with considerable abundances $>>2 \mathrm{~m}$ below the surface. The incorporation of rootand microorganism-derived organic matter (OM) in deep sedimentary subsoil does not only potentially cause an overprint of the paleoenvironmental signals recorded in such archives, followed by insecurities for the interpretation of biomarkers like e.g. $n$-alkanes or glycerol dialkyl glycerol tetraethers (GDGTs; Huguet et al., 2013a; Gocke et al., 2014c), which have been frequently used for paleoenvironmental reconstruction (e.g. McKirdy et al., 2009; Woltering et al., 2014). Root penetration might also affect terrestrial carbon $(C)$ stocks, of which considerable amounts are stored in paleosols (Marin-Spiotta et al., 2014).

So far, it is unknown whether deep roots influence the microbial community in unconsolidated deep subsoil $>1 \mathrm{~m}$. Especially their influence on long-term maintenance of microbial life after the lifetime of the root is difficult to study, but might be important in the context of $C$ sequestration in buried soils and sediments (Fisher et al., 1994; Johnson, 2014). Ancient lithified roots - rhizoliths - which often form through calcification of the root during or shortly after its lifetime (Klappa, 1980; Gocke et al., 2011) give a time-integrated insight into root-related processes over the lifespan of the root and thereafter. Here we present a multi-proxy approach to characterize both the living and fossil microbial community in deep sedimentary subsoil based on abundance and composition of five biomarker classes. The molecular approach includes two compound classes with high potential for preservation in soils and sediments: Free-extractable fatty acids (FAs) give a broad overview over plant and microbial remains 
and degradation products (Harwood and Russell, 1984; Lichtfouse et al., 1995), whereas core lipids of GDGTs (CL-GDGTs), presumed to be of fossil origin, are solely produced by some microorganisms (Suppl. Fig. 1). Thus, GDGTs with isoprenoid alkyl chains (iGDGTs) are attributed to archaea, whereas those with branched alkyl chains (brGDGTs) are biosynthesized by not yet identified bacteria (Schouten et al., 2013) potentially feeding on root remains (Huguet et al., 2012). Some of these bacteria might belong to the phylum Acidobacteria (Sinninghe Damsté et al., 2011, 2014). Further, we included the respective intact polar counterparts of these compound classes, the phospholipid FAs (PLFAs) and intact polar lipid GDGTs (IPL-GDGTs), which are attributed to living or recently deceased microorganisms due to low stability of their polar headgroups (Kindler et al., 2009; Schouten et al., 2010; Lengger et al., 2013; Suppl. Fig. 1). As third compound class, 16 S ribosomal ribonucleic acid (rRNA) genes from bacterial deoxyribonucleic acid (DNA) provided an overview of the bacterial community. Depth distribution of these biomarkers was compared with that of several parameters of pedogenic, weathering and rooting processes, including $\mathrm{C}$ contents, alkane contents and composition, abundances of living roots and root remains, density, clay contents, color and magnetic properties of a Central European sediment-paleosol sequence.

We aimed to elucidate i) which physical, chemical and biological factors influence microbial life in sedimentary deep subsoil, ii) if microbial community composition in deep subsoil is notably affected by root distribution, iii) if root effects on microbial community can be traced after lifetime of the root, and iv) whether roots maintain microbial life in terrestrial sediments for centuries or millenia.

The multi-proxy approach was applied to the Late Pleistocene loess-paleosol sequence at Nussloch, Southwest Germany, which has been investigated intensely for paleoclimate and paleovegetation (e.g. Antoine et al., 2009). The current study was performed on the uppermost $9.5 \mathrm{~m}$ of the profile $\mathrm{P}_{2011}$ (Gocke et al., 2014b; Fig. 1a), which is defined here as associated pair of Holocene soil $(0-1.1 / 1.5 \mathrm{~m}$; Fig. 1b) and Holocene deep subsoil (1.1/1.5-9.5 m) because rhizoliths (Fig. 1b-f) of Holocene ages occur continuously between 1.5 and 9 m depth (Gocke et al., 2011; Gocke et al., 2014b). Time lags between sedimentation, lasting from 35-17 ky on the one hand, and root growth on the other hand cover a wide range of $10^{2}-10^{3} \mathrm{y}$. Abundant recent roots, rhizoliths between 3 and $10 \mathrm{ky}$ in age, and root-derived biopores were observed along the profile, with ages of the latter likely between sedimentation and today (Gocke et al., 2014a). This provides the unique opportunity to assess shortterm and long-term effects of postsedimentary rooting on microbial community composition in deep subsoil. 


\section{Materials and methods}

\subsection{Study site}
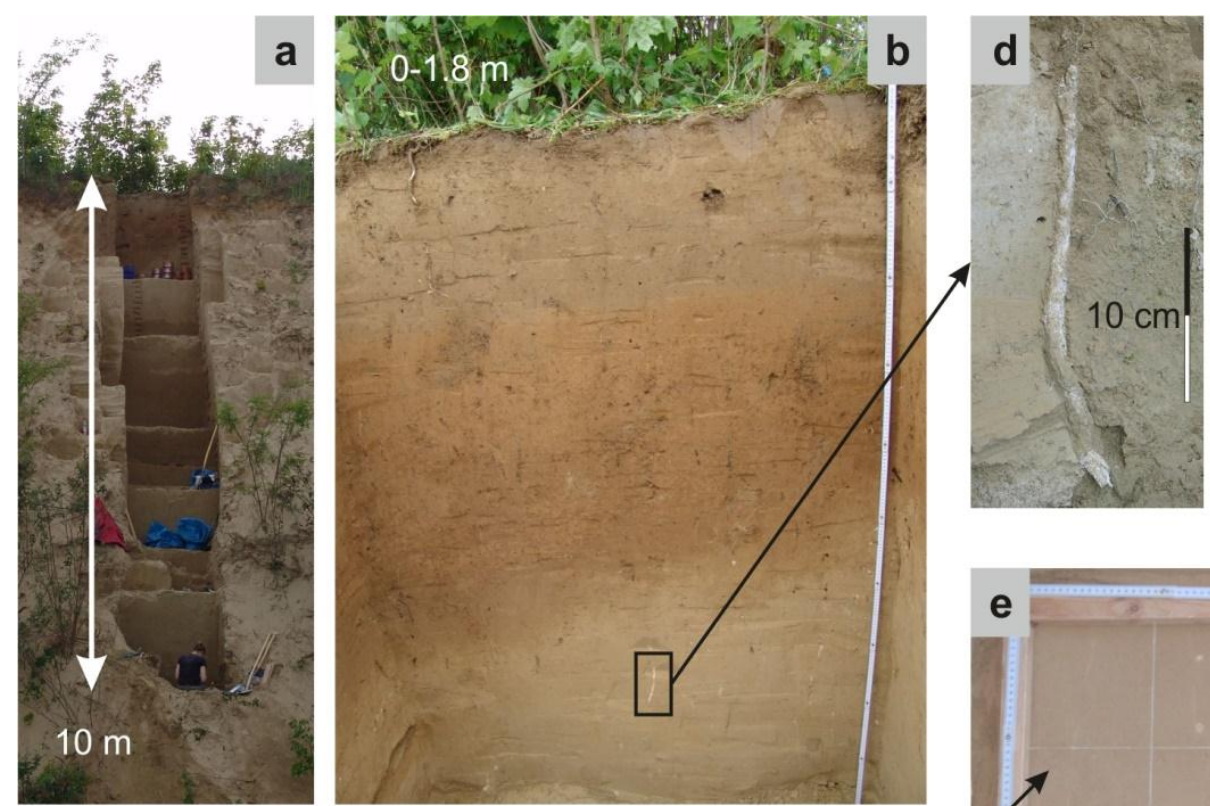

e
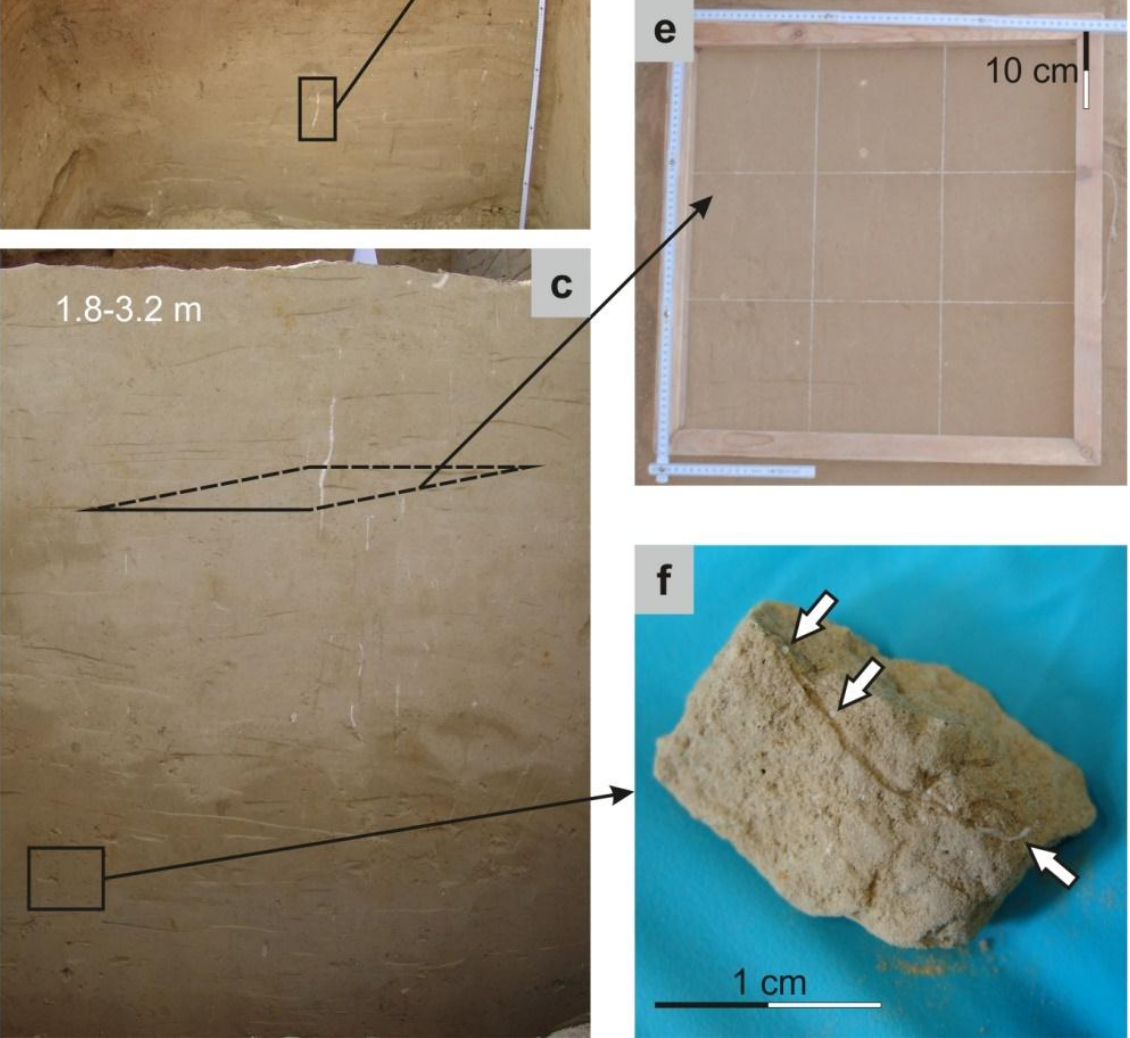

Figure 1.

Overview pictures of the Nussloch profile $(a-c)$ and detail pictures $(d-f)$ of calcified root features (rhizoliths). a) Upper Pleniglacial part of the Nussloch loess-paleosol sequence with a maximum age of $35 \mathrm{ky}$ (Antoine et al., 2009). b) 0-1.8 m depth interval, including the Holocene soil (HS; Calcic Luvisol Siltic). c) 1.8-3.2 m depth interval, with in situ, almost vertically oriented rhizoliths. d) Rhizolith, view at profile wall. e) Rhizoliths indicated as circular white spots on a horizontal level. f) Microrhizoliths (diameter $<1 \mathrm{~mm}$ ), difficult to observe at the profile wall. Picture shows one microrhizolith in longitudinal view (bottom right) and several microrhizoliths in cross section (e.g. top left). 
Detailed description of the loess-paleosol sequence at Nussloch, Southwest Germany, and its paleoenvironmental record was provided by e.g. Antoine et al. (2009) and Gocke et al. (2014b). The $13 \mathrm{~m}$ thick, $17-35 \mathrm{ky}$ old sequence includes 16 weakly developed and three well developed paleosols, as well as the 1.1-1.5 m thick Holocene Calcic Luvisol Siltic (IUSS, 2014). The recent vegetation, which relates to living roots and likely formed an unknown portion of root-related biopores throughout the profile, comprises natural broad-leaf forest and non-native robinia, as well as smaller shrubs and herbaceous plants (Gocke et al., 2013). Rhizoliths at Nussloch and nearby sites are of Holocene age between 3 and $10 \mathrm{ky}$. They occur with diameters of up to $5 \mathrm{~cm}$ but mostly $1-2 \mathrm{~cm}$ (reviewed by Gocke et al., 2014a), and were formed by roots of unknown trees or shrubs, likely including hazel, oak, beech and alder (Gocke et al., 2013). Living roots, rhizoliths, microrhizoliths and biopores occurred with maximum frequencies of ca. $800 \mathrm{~m}^{-2}, 200 \mathrm{~m}^{-2}, 12,500 \mathrm{~m}^{-2}$ and $600 \mathrm{~m}^{-2}$, respectively (Suppl. Fig. 2; Gocke et al., 2014b).

\subsection{Profile preparation, field methods and sampling}

The profile was prepared by removing $\geq 1 \mathrm{~m}$ of material from the top and the side, respectively, followed by counting of roots, root-related biopores and rhizoliths on horizontal levels (Gocke et al., 2014b, 2014c). Afterwards, $200 \mathrm{~g}$ of soil, sediment or paleosol material were collected distant from visible root remains, from topsoil down to $9.5 \mathrm{~m}$ depth in $0.5-1.0 \mathrm{~m}$ increments. After sample splitting into two aliquots, one aliquot was dried at $40^{\circ} \mathrm{C}$ and used for free FA and DNA analyses, whereas the other half was immediately cooled and kept frozen at $-18^{\circ} \mathrm{C}$ until PLFA and GDGT analyses. The sample set for DNA analyses did not include the topsoil, because microbial diversity in topsoils is very high, which would produce a bias for the other parameters. It was further reduced to seven depth intervals between $2 \mathrm{~m}$ and $9.5 \mathrm{~m}$ due to sample loss.

\subsection{Analytical methods}

\subsubsection{Free-extractable fatty acids}

Using an aliquot of dried material, free-extractable lipids were extracted and free FAs separated, derivatized and subsequently measured by GC-FID and GC-MS according to the protocol by Wiesenberg and Gocke (2015). Free FAs with a chain length of 12 to 32 carbons were quantified because they include microbial and plant tissues, as well as degradation products (Harwood and Russell, 1984). Dicarboxylic as well as unsaturated and branched free FAs were kept as separate groups of compounds, but not further assigned to specific sources, which was done for PLFAs, as multiple sources exist for most of these compounds. 


\subsubsection{Phospholipid fatty acids and glycerol dialkyl glycerol tetraethers}

An aliquot of each frozen sample was subjected to lipid extraction following a modified protocol of the Bligh-Dyer method (Bligh and Dyer, 1959; Apostel et al., 2013) with $0.15 \mathrm{M}$ citric acid, chloroform and methanol 0.8:1:2 (v/v/v). Using one half of the splitted extract, the PLFA fraction was purified over an activated silica column by elution with acetone, and derivatized for GC-MS measurement as previously described (Apostel et al., 2013). Assignment of PLFAs with chain length of 14 to 20 carbons to the respective microbial groups was performed according to literature (Zelles et al., 1999; Fernandes et al., 2013).

The second part of the extract was separated over an activated silica column into three fractions as described by Huguet et al. (2013b), with fraction F1 containing apolar lipids (eluted with $30 \mathrm{ml}$ dichloromethane), fraction F2 containing CL-GDGTs [eluted with $30 \mathrm{ml}$ dichloromethane/acetone (2:1, $\mathrm{v} / \mathrm{v})$ followed by $30 \mathrm{ml}$ dichloromethane/acetone $(1: 1, \mathrm{v} / \mathrm{v})]$, and fraction F3 containing IPL-GDGTs [eluted with $30 \mathrm{ml}$ dichloromethane/methanol $(1: 1, \mathrm{v} / \mathrm{v})$ followed by $30 \mathrm{ml}$ methanol]. A small aliquot of the IPL fraction (F3) was analyzed directly using high performance liquid chromatographyatmospheric pressure chemical ionization-mass spectrometry (HPLC-APCI-MS) to determine any carryover of CLs into the IPL fraction. The analysis showed nearly complete separation of the CL- and IPL-GDGTs. The rest of the fraction F3 was subjected to acid methanolysis $\left(24 \mathrm{~h}\right.$ at $100{ }^{\circ} \mathrm{C}$ in $1 \mathrm{M}$ $\mathrm{HCl} /$ methanol) to cleave off the polar head groups of IPL-GDGTs. CL- and IPL-derived GDGTs were analysed by HPLC-MS using a procedure described by Huguet et al. (2013b).

\subsubsection{Bacterial 16S rRNA genes}

Prior to analysis of the bacterial genetic fingerprint, a sterility test was successfully performed. Metagenomic DNA was extracted in replicates from $0.5 \mathrm{~g}$ aliquots of dry sample material using the FastDNA $®$ SPIN Kit for Soil (MP Biomedicals). Bacterial 16S rRNA genes were amplified with primers 27f/907mr (Schellenberger et al., 2010). Primer $27 \mathrm{f}$ was labeled with infrared dye 700 for t-RFLP (terminal restriction fragment length polymorphism) analyses. PCR (polymerase chain reaction) products were purified with a DNA Gel Extraction Kit (Millipore, MA) and single-stranded extensions at terminal ends were removed with mung bean endonuclease digest (Egert and Friedrich, 2003). Subsequent restriction digestion of PCR products was performed with Mspl (Degelmann et al., 2009). DNA concentrations were determined with a DNA Quantification Kit (Invitrogen, Germany) and

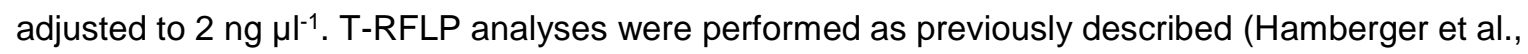
2008). PCR products from all samples were pooled and used to construct one 16 S rRNA gene library. 
Amplicons were cloned into Escherichia coli JM 109 competent cells using the PGEM-T Vector System II (Promega, WI). Inserted 16S rRNA gene fragments were re-amplified and sequenced (Messing, 1983; MacroGen, South Korea). In total, 270 different inserts were sequenced. Identification of phylotypes was done by RDP classifier. Based on in silico digestion, terminal restriction fragments detected by software GelQuest (version 3.1.7, SequentiX GmbH, Germany) were manually affiliated to sequenced genotypes. Ribonucleic acid (RNA), representing viable microorganisms due to its presumably fast degradation, was not analysed, because i) very low DNA contents in Quaternary sediments like loess (Liu et al., 2007; current study) imply that RNA is likely too low for amplification and further analysis, and ii) rarefaction analysis (Suppl. Fig. 3) revealed that even DNA results are reliable solely at the phylum level.

\section{$\underline{2.4 \text { Statistic evaluation }}$}

Variables within the individual datasets (free FAs, PLFAs, core GDGTs, intact polar GDGTs and DNA) were reduced by factor analysis. Factor values of most significant factors were compared between the datasets by canonical correlation analysis, and redundancy values for the datasets were computed. Further, environmental and profile parameters (EPP) significantly affecting the depth distribution of the biomarker groups were identified by regression analysis. The bulk elemental composition, measured via X-ray fluorescence analysis (Gocke et al., 2014b), did not reveal significant correlations with any of the biomarker sets and is therefore not shown. A significance level $=0.1$ was chosen, because of $i$ ) small size of the sample set, ii) investigation of natural samples in contrast to samples from laboratory experiments performed under controlled conditions, and iii) heterogeneous nature of the sample set in terms of age and material. All statistical analyses were performed with Statistica 6.0 (StatSoft, Tulsa, USA).

\section{Results and Discussion}

\subsection{Lipid distribution}

Lipids were more abundant in the topsoil than in subsoil collected at $1 \mathrm{~m}$ depth (Fig. 2a-d), and concentrations in deep subsoil reached max. $28 \%$ of the respective topsoil value.

\subsubsection{Distribution patterns of free-extractable and phospholipid fatty acids}

Free FA distribution patterns were mostly dominated by short-chain homologues (Gocke et al., 2014c; $\mathrm{C}_{12-19}$; Fig. 2a). The ratio of short- vs. long-chain $\left(\mathrm{C}_{20-32}\right)$ free FAs (Rs:L) was mostly > 1.2 (Suppl. Tab. 1), indicating the dominance of belowground OM including microbial remains, rhizodeposits and 
degradation products over higher plant aboveground biomass inputs (Harwood and Russell, 1984). Contents of unsaturated free FAs $\left(\mathrm{C}_{16,18,19}\right)$ were low due to their high degradability. Branched free FAs $\left(b_{12} C_{12-18}\right)$, most likely originating from gram positive $\left(\mathrm{Gram}^{+}\right)$bacteria, and dicarboxylic acids $\left(\mathrm{C}_{9-}\right.$ $11,18,20$ ), deriving mainly from plant above- and belowground tissues, contributed only to a minor extent to free FAs.
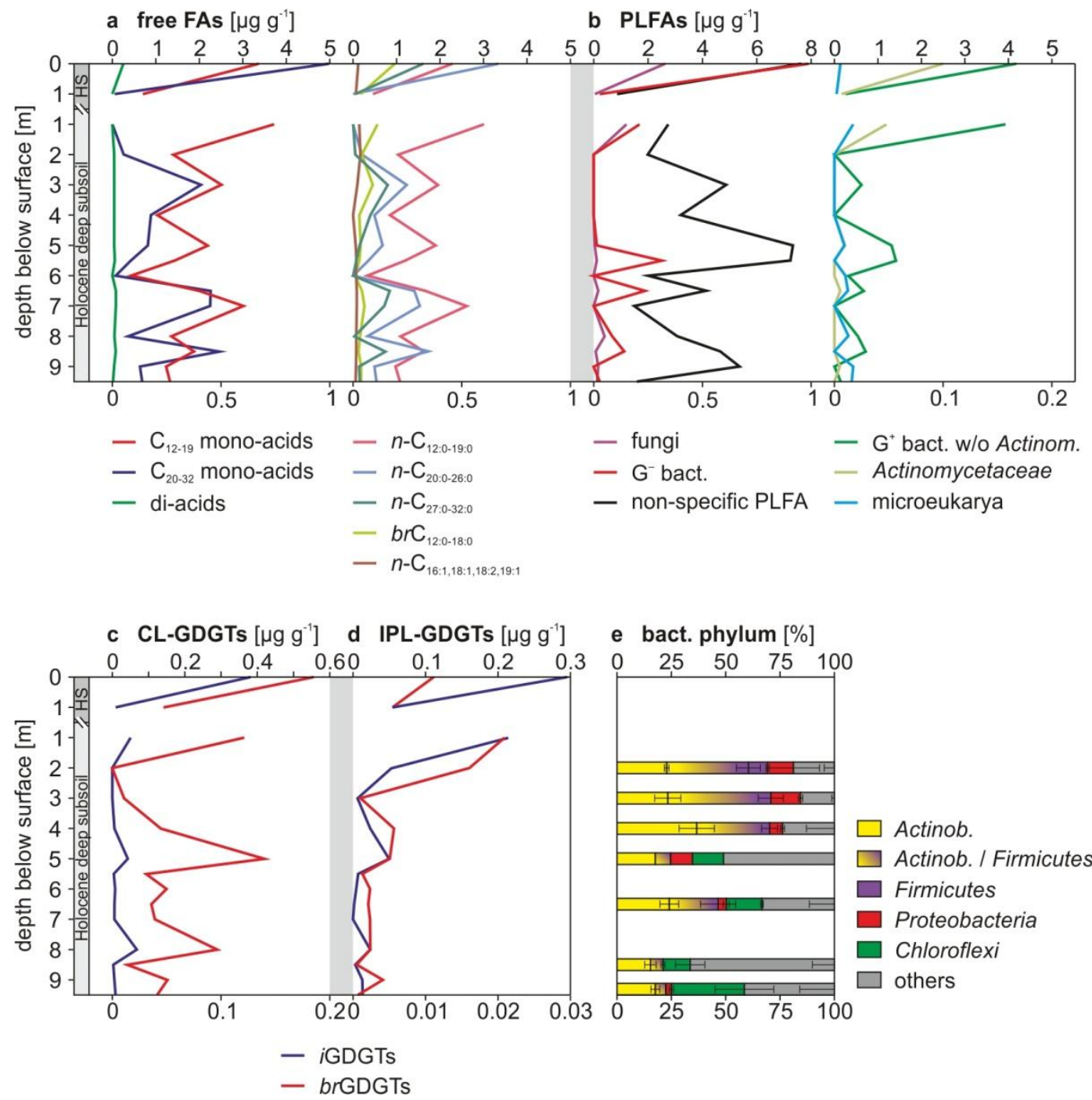

Figure 2.

Biomarker classes representing fossil microorganisms (free fatty acids [FAs], core lipid glycerol dialkyl glycerol tetraethers [CL-GDGTs] and bacterial genetic fingerprint) and living microorganism communities (phospholipid fatty acids [PLFAs] and intact polar lipid glycerol dialkyl glycerol tetraethers [IPL-GDGTs]). Diagrams a-d show concentrations of lipids, where in each diagram the upper x-axis refers to lipid contents in the Holocene soil (HS, 0-1 m), and the lower x-axis refers to lipid contents in the deep subsoil 1-9.5 m. a) Free FA contents. The left diagram contains contents of total (saturated, unsaturated and branched) short-chain $\left(\mathrm{C}_{12-19}\right)$ and long-chain $\left(\mathrm{C}_{20-}\right.$ 32) monocarboxylic acids as well as dicarboxylic acids $\left(\mathrm{C}_{9-11,18,20}\right)$ deriving from cutin and suberin biopolymers (Kolattukudy, 1984), whereas the right diagram displays contents of mainly microorganism-derived saturated 
short-chain free $F A s\left(C_{12: 0-19: 0)}\right.$, plant-derived saturated long-chain $\left(\mathrm{C}_{20: 0-26: 0}\right)$ and very long-chain free $F A s\left(C_{27: 0-}\right.$

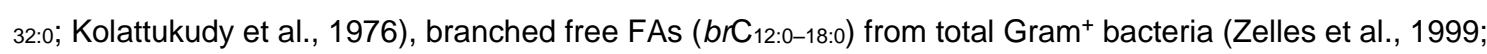
Fernandes et al., 2013), as well as microorganism- and plant-derived unsaturated free $F A s\left(C_{16: 1,18: 1,18: 2,19: 1}\right.$; Kolattukudy et al., 1976; Harwood and Russell 1984). Please note that branched free FAs did not enable distinction between Actinomycetaceae and other Gram+ bacteria. b) Concentrations of specific PLFAs attributed

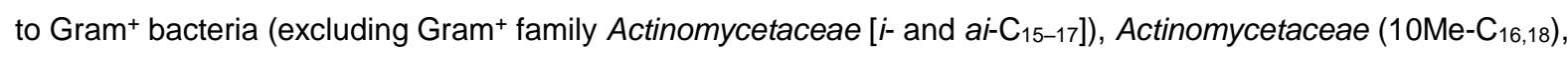

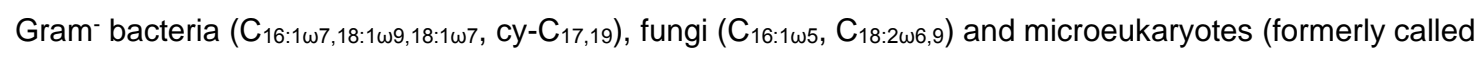
protozoa [ $\mathrm{C}_{20: 4 \omega 6}$; Zelles et al., 1999; Fernandes et al., 2013), as well as of non-specific PLFAs (saturated C 14:018:0). c) Concentrations of CL-GDGTs, divided into archaea-derived isoprenoid GDGTs (iGDGTs; m/z 1292-1302) and bacteria-derived branched GDGTs (brGDGTs; m/z 1018-1050; Schouten et al., 2013). d) Concentrations of IPL-GDGTs, divided into iGDGTs and brGDGTs. e) Distribution of phylogenetic groups, based on 16S rRNA genes from DNA. Phylogenetic groups accounting for $\leq 3 \%$ as well as portions of unclassified sequences and phylogenetic groups occurring solely in one depth are summarized in the artificial group 'others'.

Specific PLFAs suggested a dominance of bacteria (methylated, cyclo- and most mono-unsaturated FAs) over fungi ( $\mathrm{C}_{16: 1 \omega 5,18: 2:}$ Fig. 2b) in all depth intervals except for $9 \mathrm{~m}$ (Suppl. Tab. 1). At four sampling depths between 5.0 and $8.5 \mathrm{~m}$, ratio of bacterial to fungal PLFAs (RB:F) exceeded the value of the topsoil by a factor ranging between 2 and 4 . Higher relative portions of fungi occurred solely in the lowermost part of the profile $(8.0,9.0$ and $9.5 \mathrm{~m}$ ) and might be attributed either to pedogenic conditions in well-developed paleosols or to postsedimentary penetration by fossil and/or living roots, both of which coincide in these depths (Gocke et al., 2014b). The ratio of Gram+ (methylated FAs) to gram negative (Gram-) bacteria (cyclo- and most mono-unsaturated FAs) RP:N was approximately twice as high in deeper parts of the Holocene soil (1 m depth) compared to surface soil (Suppl. Tab. 1). Between 5.5 and $9.5 \mathrm{~m}$, very low $\mathrm{R}_{\mathrm{P}: \mathrm{N}}$ resulted from high contents of $\mathrm{Gram}^{-}$bacterial PFLAs.

\section{$\underline{\text { 3.1.2 Distribution patterns of core and intact polar glycerol dialkyl glycerol tetraethers }}$}

Bacterial and archaeal GDGTs were present in all samples (Fig. 2c, d), with the ratio of isoprenoid to branched GDGTs (Ri:b; Yang et al., 2014) ranging between 0.03 and 0.68 for core GDGTs and between 0.19 and 2.65 for intact polar GDGTs (Suppl. Tab. 1). Archaea predominated over bacteria only in topsoil and at the bottom of the sequence according to IPL-GDGT analyses. During recent years, studies emphasized the ubiquitous occurrence of archaea and especially one phylum, Thaumarchaeota, in surface soils (uppermost 0.2 m; Harvey et al., 1986; Buckley et al., 1998). The current work thus provides extended knowledge on the occurrence of archaea in deep subsoil. The relative amounts of iGDGTs vs. brGDGTs decreased for both core and intact polar GDGTs from 0 to 1 
$\mathrm{m}$ and from 0 to $2 \mathrm{~m}$, respectively (Suppl. Tab. 1). Below these depths, Ri:b was mostly higher for intact polar (25-65\%) than for core GDGTs (3-33\%; Suppl. Tab. 1), which might be due to the more labile nature of the predominantly phospho-headgroup of brGDGTs compared to the usually glycoheadgroup of iGDGTs (Harvey et al., 1986).

\section{$\underline{3.2 \text { Bacterial genetic fingerprint }}$}

Phylotypic composition of bacterial DNA in deep subsoil was dominated by Actinobacteria, Firmicutes, Chloroflexi and Proteobacteria, besides minor abundance of Acidobacteria, Bacteroidetes and candidate division OP11 (Fig. 2e). Throughout identified phylogenetic groups with abundances $>3 \%$, the predominance of Gram+ bacterial phyla (Actinobacteria and Firmicutes) at 2, 3, 4 and $6.5 \mathrm{~m}$ matched well the absence of Gram- bacterial PLFAs at 3 and $6 \mathrm{~m}$, but not at $5 \mathrm{~m}$ (Suppl. Tab. 1). Further, the much lower RP:N in lower parts of the loess-paleosol sequence, excluding $9 \mathrm{~m}$, agreed with higher portions of Gram- bacteria (Chloroflexi and Proteobacteria).

\section{$\underline{3.3 \text { Fossil and living microbial communities in Holocene soil and deep subsoil }}$}

The multi-proxy approach indicated the dominance of bacterial signatures over fungal, archaeal and microeukaryotic ones throughout the Holocene soil and deep subsoil, suggesting a microbial community typical for the vadose subsurface (Whitman et al., 1998; Fierer et al., 2003). Also, bacterial DNA composition resembled that in modern soils (Janssen, 2006). However, as bacterial genes were already close to detection limit, the presumably less abundant archaeal or fungal genes were not investigated. The deep subsoil properties of the loess-paleosol sequence were strengthened by its increased ratio of bacterial to fungal PLFAs compared to topsoil (Suppl. Tab. 1), which matches previous studies showing an increase of the latter with soil depth (Holden and Fierer, 2005; Stone et al., 2014). Further, the high ratio of Gram+ to Gram- PFLAs below the topsoil (Suppl. Tab. 1) was already described for the uppermost $2 \mathrm{~m}$ of agricultural and grassland soils (Blume et al., 2002; Fierer et al., 2003).

Presence of PLFAs and intact polar GDGTs, though in amounts up to one order of magnitude lower compared to their free/core counterparts, revealed the presence of living microorganisms at any depth throughout the profile, including the deep subsoil of Late Pleistocene age. This contradicts the traditional assumption of organic compounds being incorporated solely during deposition of terrestrial sediments (Conte et al., 2003). Intact polar GDGTs contributed less than $15 \%$ to total GDGTs below $2 \mathrm{~m}$ (Suppl. Fig. 4b), similarly to brGDGT data from topsoils (Peterse et al., 2010), whereas the percentages of PLFAs from total FAs scattered between 24\% and $88 \%$ (Suppl. Fig. 4a). 

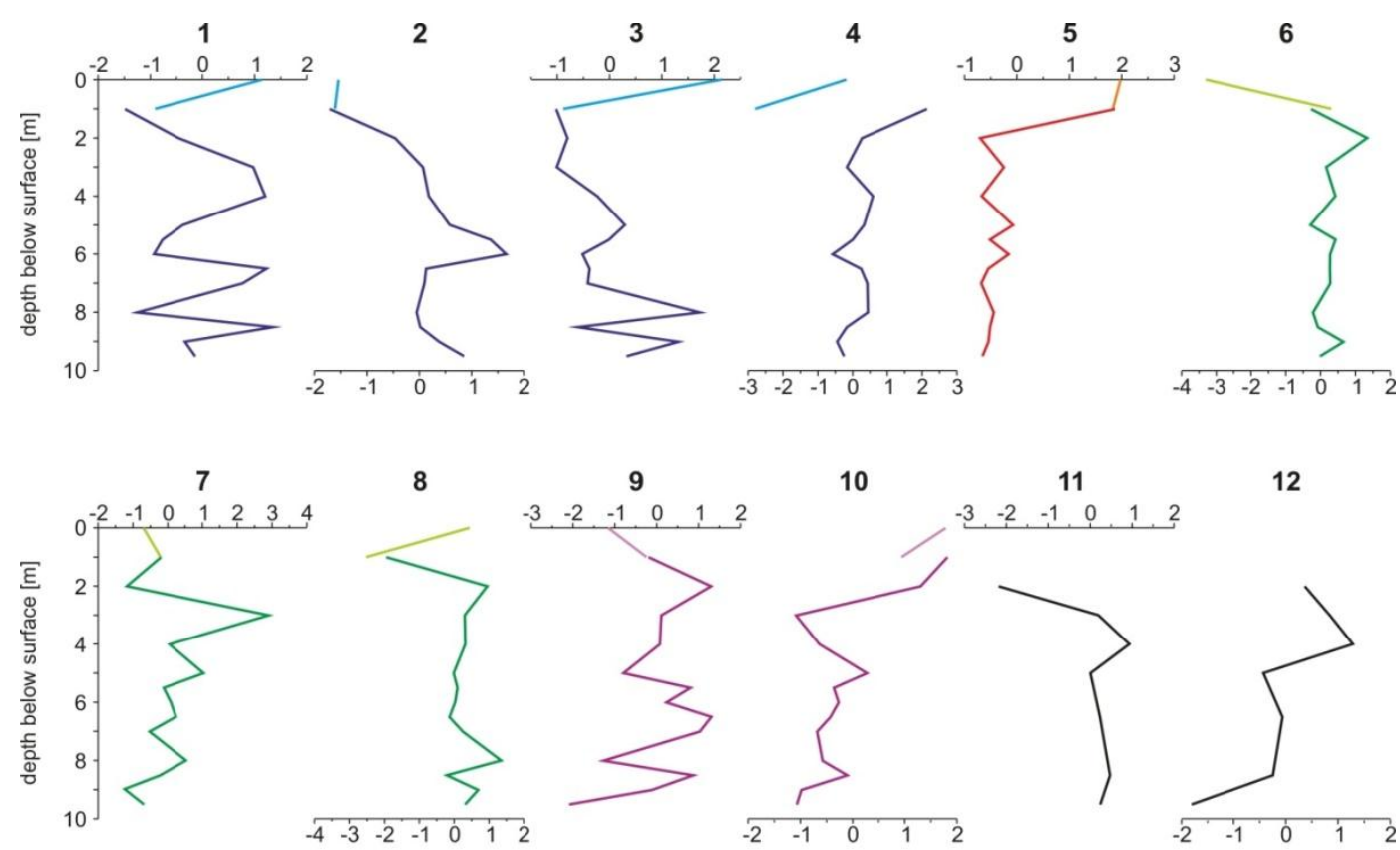

12

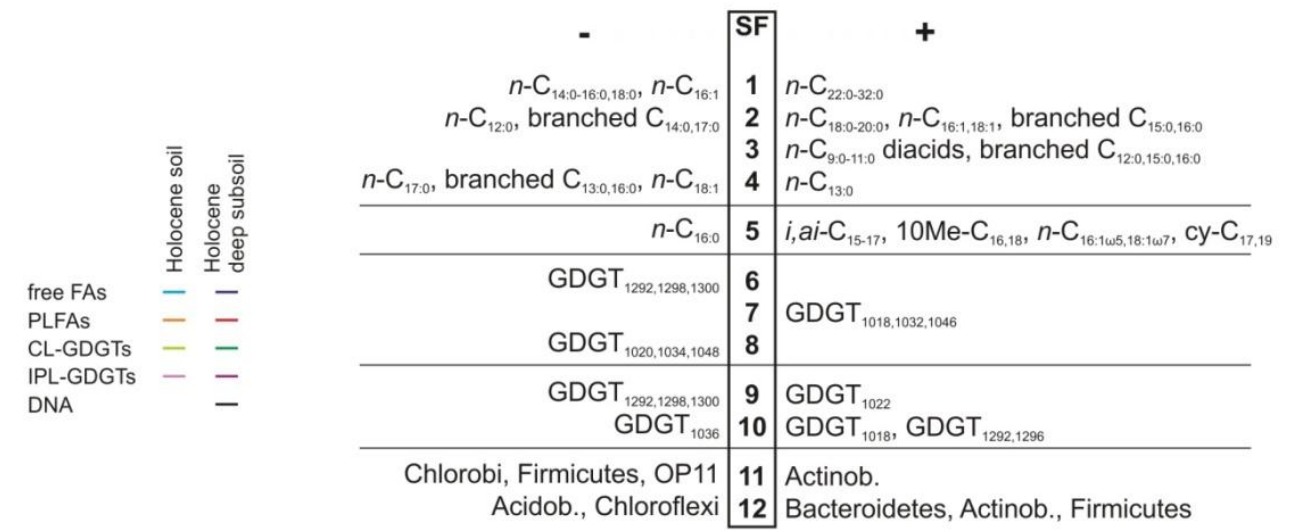

Figure 3.

Statistical factors (SF) of the biomarker groups obtained by factor analysis. Compounds with strong positive and negative loadings ( $\mathrm{min} .>0.6$ or $<-0.6$, but mostly $>0.9$ or $<-0.9$ ) on these factors are listed for free FAs (SF $1-$ 4), PLFAs (SF 5), CL-GDGTs (SF 6-8), IPL-GDGTs (SF 9, 10) and DNA (SF 11, 12), respectively.

FAs, GDGTs and bacterial DNA are produced independently from each other and partially by different source organisms. To elucidate the degree of overlap between individual biomarker data sets, and consequently disentangle the time range represented by free/core lipids, redundancy values between the five biomarker classes (Tab. 1) were calculated after reduction of the respective data sets by factor analysis. Free/core lipids of FAs and GDGTs could be well explained by the respective other free/core lipid group with $65 \%$ and $52 \%$ conformity, whereas they were less well predictable by their intact polar counterpart and the respective intact polar lipid group of the other lipid category. Best predictor of free FAs and core GDGTs was DNA with $88 \%$ and $79 \%$ redundancy. Similarly, DNA was better explained by free FAs and core GDGTs than by intact polar lipids. The high conformity of free FAs and core GDGTs with DNA, together with the potential of DNA to be preserved outside a cell in soils for 
centuries to millenia (Agnelli et al., 2007), support the assumption that these lipids represent a timeintegrated signal of microorganism remains accumulated since sedimentation until today.

Table 1.

Redundancies given in \%, describing the portion, to which extent a predictor data set can explain the outcome data set. The data derives from canonical correlation analysis of the five microbial biomarker classes investigated.

\begin{tabular}{|l|c|c|c|c|c|}
\hline Outcome data set & Free FAs & PLFAs & CL-GDGTs & IPL-GDGTs & $\begin{array}{c}\text { Bacterial } \\
\text { phylotypes }\end{array}$ \\
\hline Predictor data set & & & & & \\
\hline Free FAs & 38 & 31 & 52 & 31 & 80 \\
\hline PLFAs & 65 & 38 & 38 & 42 & 35 \\
\hline CL-GDGTs & 51 & 56 & 41 & 65 & 31 \\
\hline IPL-GDGTs & 88 & 45 & 79 & 65 \\
\hline Bacterial phylotypes & & & & \\
\hline
\end{tabular}

\subsection{Influence of environmental setting on deep subsoil microorganisms}

We aimed to determine the linkage of living and fossil microorganisms to biological, physical or chemical conditions that prevailed during phases of sedimentation, pedogenesis, rooting or inbetween. Therefore, the twelve statistical factors (SF; Fig. 3), obtained after reduction of the individual compounds of each biomarker class by factor analysis, were tested for correlation with the following 13 environmental and profile parameters (EPP; Tab. 2, Suppl. Fig. 2): (1) organic carbon (Corg) and (2) carbonatic carbon ( $\left.\mathrm{C}_{\text {carb }}\right)$ contents; $(3)$ contents of $n$-alkanes $\left(n-\mathrm{C}_{15-37}\right)$, deriving from microorganisms and higher plants; (4) alkane carbon preference index ( $\left.\mathrm{CPI}_{a \mid k}\right)$ enabling the distinction between fresh plant aboveground biomass and microbial and degraded OM; frequencies of (5) living roots, (6) rhizoliths and (7) root-derived biopores; (8) dry bulk density; (9) clay contents; (10) color indices $\mathrm{a}^{*}$ and (11) $\mathrm{L}^{*}$; (12) magnetic susceptibility measured at $0.3 \mathrm{kHz}(\mathrm{k})$, and (13) S-ratio of soil or sediment. All data except for alkane content and $\mathrm{CPl}_{\text {alk }}$ (Gocke et al., unpublished data) were adopted from Gocke et al. (2014b).

Table 2.

Significance levels of the correlations between twelve statistical factors (SF) derived from the five investigated biomarker groups, and 13 environmental and profile parameters (EPP). All EPP were adapted from Gocke et al. 
(2014b) except for alkane contents and CPlalk. For depth diagrams of EPP see Suppl. Fig. 2; correlation coefficients are listed in Suppl. Tab. 2 .

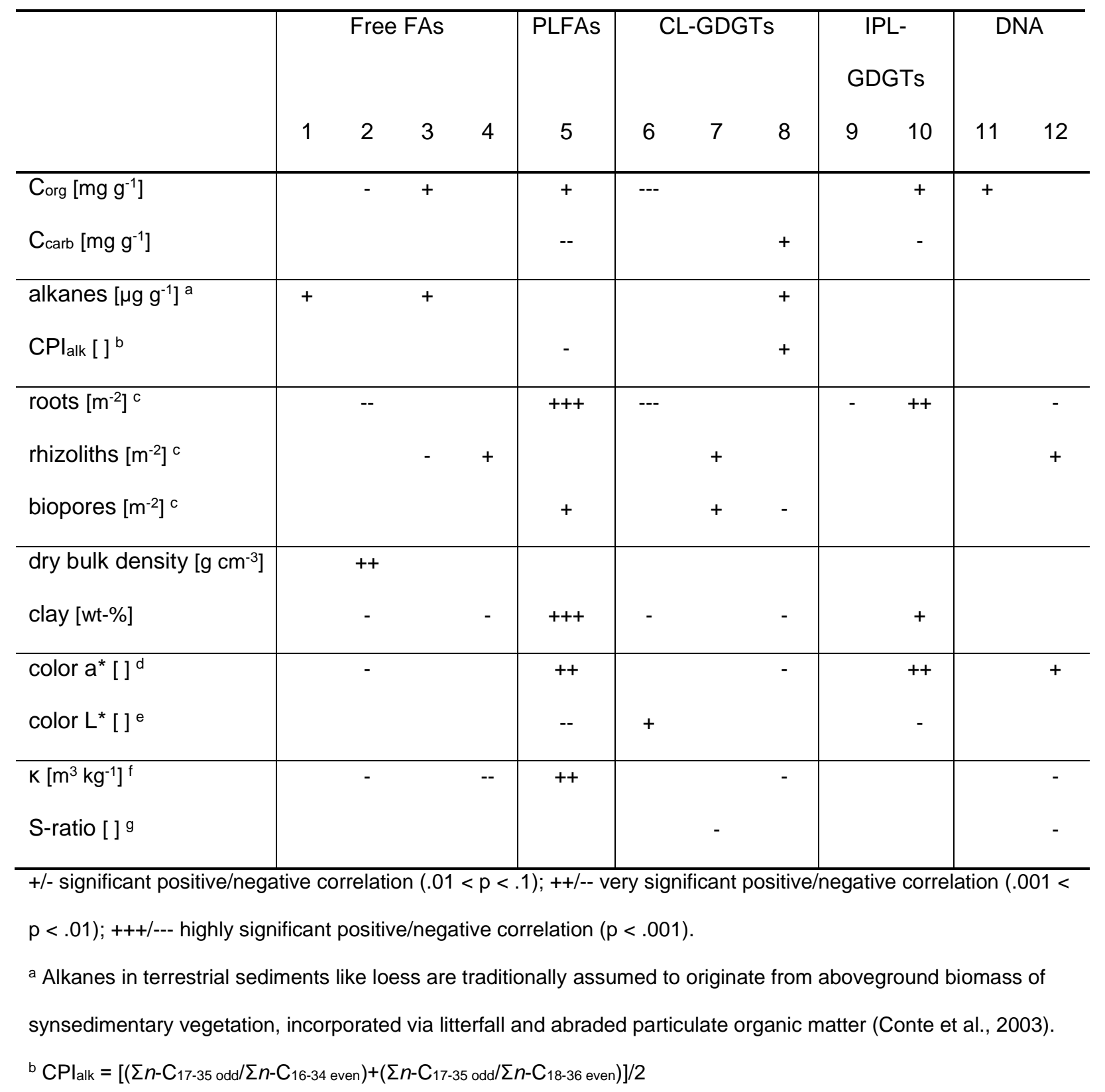

Carbon preference index of odd over even $n$-alkane homologues. High $\mathrm{CPI}_{\text {alk }}$ indicates dominance of fresh plant aboveground biomass, whereas low values suggest predominantly microorganism-derived and degraded organic matter (Cranwell, 1981).

${ }^{\mathrm{c}}$ Frequencies of roots, rhizoliths and biopores were determined on horizontal areas using a grid with dimension $0.5 \times 0.5 \mathrm{~m}$ (Gocke et al., 2014b).

${ }^{d}$ High $a^{*}$ values indicate reddish color and low values green color (CIE, 1931). Throughout the investigated profile, highest $\mathrm{a}^{*}$ in the Holocene soil indicates pedogenic processes like formation of iron oxides, whereas in sedimentary deep subsoil, high $a^{*}$ (mostly loess > paleosol) likely result from hydromorphic bleaching. 
e High $L^{*}$ values characterize light color and low values dark color (CIE, 1931). Although organic matter content can strongly influence $L^{*}$, Corg and $L^{*}$ do not correlate with each other at Nussloch. Rather, high $L^{*}$ may result from hydromorphic bleaching of paleosols (Gocke et al., 2014b).

${ }^{\mathrm{f}}$ Measure for concentration and magnetic grain size variation of ferrimagnetic minerals (Maher, 2011). Strong pedogenesis is represented by very high $\mathrm{K}$ in the Holocene soil, but contrary to Eurasian loess deposits, high $\mathrm{k}$ of the periglacial Nussloch loess-paleosol sequence represents seasonal waterlogging and subsequent in situ weathering rather than pedogenesis (Gocke et al., 2014b).

${ }^{g}$ Parameter for the relative portions of ferrimagnetic vs. antiferromagnetic minerals (Wang et al., 2006). More intense pedogenesis caused lower S-ratio and weak pedogenesis higher S-ratio in the loess-paleosol sequence, whereas the opposite holds true for the Holocene soil.

\subsubsection{Free-extractable fatty acids}

Positive correlation of long-chain $\left(\mathrm{C}_{22-32} ; \mathrm{SF} 1\right)$ and dicarboxylic free $\mathrm{FAs}\left(\mathrm{C}_{9-11} ; \mathrm{SF} 3\right)$ with alkane contents (Fig. 2, Tab. 2) confirmed the higher plant origin of the former and suggested the same for the latter, because average chain length of long-chain alkanes $\left(\mathrm{C}_{25-37}\right)$, which was mostly $>29$ at the Nussloch deep subsoil (Gocke et al., 2013), indicated major contribution of higher plant leaf waxes (Eglinton et al., 1962). Gram+ bacteria-derived branched free FAs ( $C_{14,17} ;$ SF 2; $C_{12,15,16}$; SF 3; $C_{13,16}$; SF 4) positively correlated with indicators of advanced pedogenesis (high Corg and clay contents) and weathering (high $\mathrm{a}^{*}$ and $\mathrm{k}$ ), low density, abundant living roots and high alkane contents. They negatively correlated with rhizolith abundances (SF 3, 4), suggesting that Gram+ bacteria in subsoil feed mainly on old bulk OM and not younger plant-derived OM (Kramer and Gleixner, 2006). Composition of higher plant-derived long-chain free FAs was probably hardly affected by microbial overprint, as implied by the absence of correlation between long-chain and dicarboxylic free FAs, and recent roots. Plant-derived free FAs can thus be used as (paleo)environmental tracer (Reiffarth et al., 2016), as long as material free of root remains is collected.

\subsubsection{Phospholipid fatty acids}

The SF created from PLFA composition (SF 5) yielded factor loadings similarly high for all of the compounds with positive loading on this SF, i.e. Gram+ bacteria, Actinomycetaceae, Gram- bacteria and fungi, and showed significant to highly significant correlations with nine EPP. Living bacteria and fungi were associated with depths characterized by strong pedogenesis and weathering. For eight out of nine EPP, the chronological context is ambiguous, as they might be of synsedimentary / synpedogenic nature or could partially be related to postsedimentary waterlogging effects (high $\mathrm{a}^{*}$ and K) or later pedogenic (high $\mathrm{C}_{\text {org }}$ and low $\mathrm{L}^{*}$ due to $\mathrm{OM}$ accumulation, low $\mathrm{C}_{\text {carb }}$ due to carbonate 
dissolution, low $\mathrm{CPl}_{\text {alk }}$ from degradation, high clay) and rooting phases (abundant biopores from recent/former roots). Root abundances, showing one of the highest significances throughout the sample set $(p=.00001)$ with SF 5 , emphasized the role of the recent vegetation for living microbial community in the deep subsoil. Large similarities of short-chain free FAs and PLFAs were found: Both showed that Gram+ bacteria and Actinomycetaceae prefer depths characterized by stronger pedogenesis and weathering as well as recent rooting (SF 2-5). This implies that notable parts of short-chain free FAs in terrestrial sediments might result from rhizodeposits and microorganisms stimulated by plant roots, and thus represent a mixed paleoenvironmental signal from a broad timespan.

\subsubsection{Core lipid glycerol dialkyl glycerol tetraethers}

In terms of core GDGTs, archaeal GDGT $1292,1298,1300$ (SF 6) were more abundant in depths that are influenced by both ancient/long-term pedogenic processes (high $\mathrm{Corg}_{\text {ond }}$ and clay contents, low $L^{*}$ ), and recent rooting. The correlation of archaeal iGDGTs and recent roots points to a similar direction as previous studies, which demonstrated the increased occurrence of bacterial brGDGTs in vicinity of roots (Huguet et al., 2013a). Analogously to brGDGT source organisms (Weijers et al., 2010; Ayari et al., 2013), our findings thus suggest that iGDGT source organisms might have a heterotrophic metabolism as well. However, the high significance of this relation as well as the correlation between core GDGTs, considered as fossil markers, and recent roots was unexpected. The latter might indicate low stability of archaeal intact polar GDGTs in soil, leading to a fast release of the respective core GDGTs. The assumed link of archaea mainly to recent and less to ancient rooting is enforced by the absence of correlations between any archaeal core and intact polar GDGTs (SF 6, 9, 10) and rhizoliths or biopores. Short residence times of archaeal intact polar GDGTs of few days to weeks were shown for marine sediments (Ingalls et al., 2012), and might be similar in soils. Among bacterial compounds, homologues with two cyclopentyl moieties (GDGT $1018,1032,1046$; SF 7) occurred mainly in depths strongly affected by ancient rooting (abundant rhizoliths, biopores) or by weathering (low Sratio). Homologues with one cyclopentyl moiety (GDGT $1020,1034,1048$; SF 8) were also more abundant in weathered depths (low $\mathrm{C}_{\text {carb }}$ and alkane content, low $\mathrm{CPI}_{\text {alk, }}$ abundant biopores, high clay content, $\mathrm{a}^{*}$ and $\mathrm{k})$.

\section{$\underline{3.4 .4 \text { Intact polar glycerol dialkyl glycerol tetraethers }}$}

Archaeal intact polar GDGTs (GDGT $1292,1298,1300 ;$ SF 9; GDGT 1292,1296 ; SF 10) were most abundant in depths affected by recent rooting, similar to their CL counterparts (SF 6), whereas the significance 
level was distinctly lower than for SF 6. In a Central Chinese soil profile, Ayari et al. (2013) observed enriched intact polar GDGTs in close vicinity of living roots. This suggests that the respective source organisms were strongly stimulated by postsedimentary penetrating roots, which is in agreement with our findings. The two bacterial intact polar GDGTs with commonly highest abundance in soil, GDGT $_{1022}$ and GDGT 1036 , generally loaded opposite of archaeal GDGTs within SF 9 and SF 10, and thus also behaved contrary to homologues with one $\left(\mathrm{GDGT}_{1020,1034,1048)}\right)$ and two cyclopentyl moieties (GDGT 1018,1032,1046; SF 7, 8). In summary, core and intact polar GDGTs revealed that source organisms prefer places of stronger reworking, except for GDGT $_{1022}$ and GDGT $_{1036}$, potentially deriving from a different group of microorganisms than other GDGTs.

\subsubsection{Bacterial genetic fingerprint}

Based on the 16S rRNA genetic fingerprint, positive correlation of Actinobacteria with high $\mathrm{C}_{\mathrm{org}}$ contents (SF 11) supported free FA and PLFA results (SF 2, 3, 5). However, a direct comparison of DNA and PLFA-based community composition needs to be regarded with caution as both datasets have deviating taxonomic accuracy. Actinobacteria and Firmicutes (SF 12) preferred depths strongly affected by seasonal waterlogging (high $\mathrm{a}^{*}$, low $\mathrm{k}$ ), and were abundant in depths with rhizoliths, but not in recently rooted depths, which contradicts free FA and PLFA results (SF 2-5). This discrepancy may result either from the smaller size of the DNA sample set excluding the peak root abundances in the Holocene soil, or may demonstrate the time-integrated character of the DNA signal in terrestrial sediments, covering a wide range from potentially fossil to recent microbial communities. The latter hypothesis is supported by the DNA-based SF 12 which is the only statistical factor that correlates with both recent roots and rhizoliths (Tab. 2), corresponding to ancient and recent $C$ input, whereas other statistical factors correlated solely with one of them.

The identified correlations between biomarker datasets and environmental parameters should be further validated in experimental studies on recent systems allowing for replicate analysis of such relations.

$\underline{3.5}$ Root-related long-term alteration of deep subsoil microbial communities - consequences and open questions

Generally, the microbial community composition in deep subsoil was affected by pedogenic and weathering factors, as shown by correlations with clay, $a^{*}$ and $\mathrm{k}$. Additionally, our results emphasize Corg as main driving factor. This supports the assumption that $\mathrm{Corg}_{\text {is }}$ crucial for microbial abundance (Helgason et al., 2014), community (Hansel et al., 2008) or long-term survival of microorganisms in 
terrestrial sediments (Breuker et al., 2001), presumably due to close spatial association of microorganisms and $\mathrm{C}_{\mathrm{org}}$ (Holden and Fierer, 2005). As roots represent an important source of

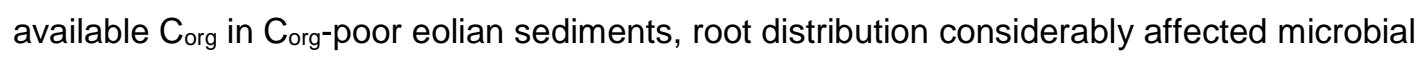
communities. At Nussloch, the main root effect was that intact polar lipids representing living microorganisms were affected solely by recent root features, which includes partially also biopores. In contrast, microbial remains reflecting an ancient or time-integrated signal, i.e. free/core lipids and DNA, correlated predominantly with ancient root features including rhizoliths and biopores but simultaneously also with living roots.

These findings strongly suggest that microbial life in sedimentary deep subsoil is not only altered exclusively by postsedimentary rooting, but may thrive more or less continuously long after the lifetime of the root in remaining hotspots. This is potentially stimulated by successive generations of roots partially re-utilizing existing root-derived biopores (Fig. 4), a mechanism well known for crops in shallow subsoil (Kautz et al., 2013). Analogously to deep sea sediments (Takano et al., 2010) or topsoils (Dippold and Kuzyakov, 2015), in ancient terrestrial sediments and root systems like at the Nussloch loess-paleosol sequence, microorganisms may thus feed on microbial degradation products and, in case of terrestrial settings, rhizodeposits even millenia after decay of the initial microorganisms and/or root. Likely, ongoing microbial dynamics in sedimentary deep subsoil is a widespread phenomenon. As shown by a survey of root and root feature distribution in sedimentary deep subsoils of various age and texture throughout Central and Southeast Europe (Gocke et al., 2014a), deep roots entering soil parent material are not an exception but likely abundant at many sites globally. 


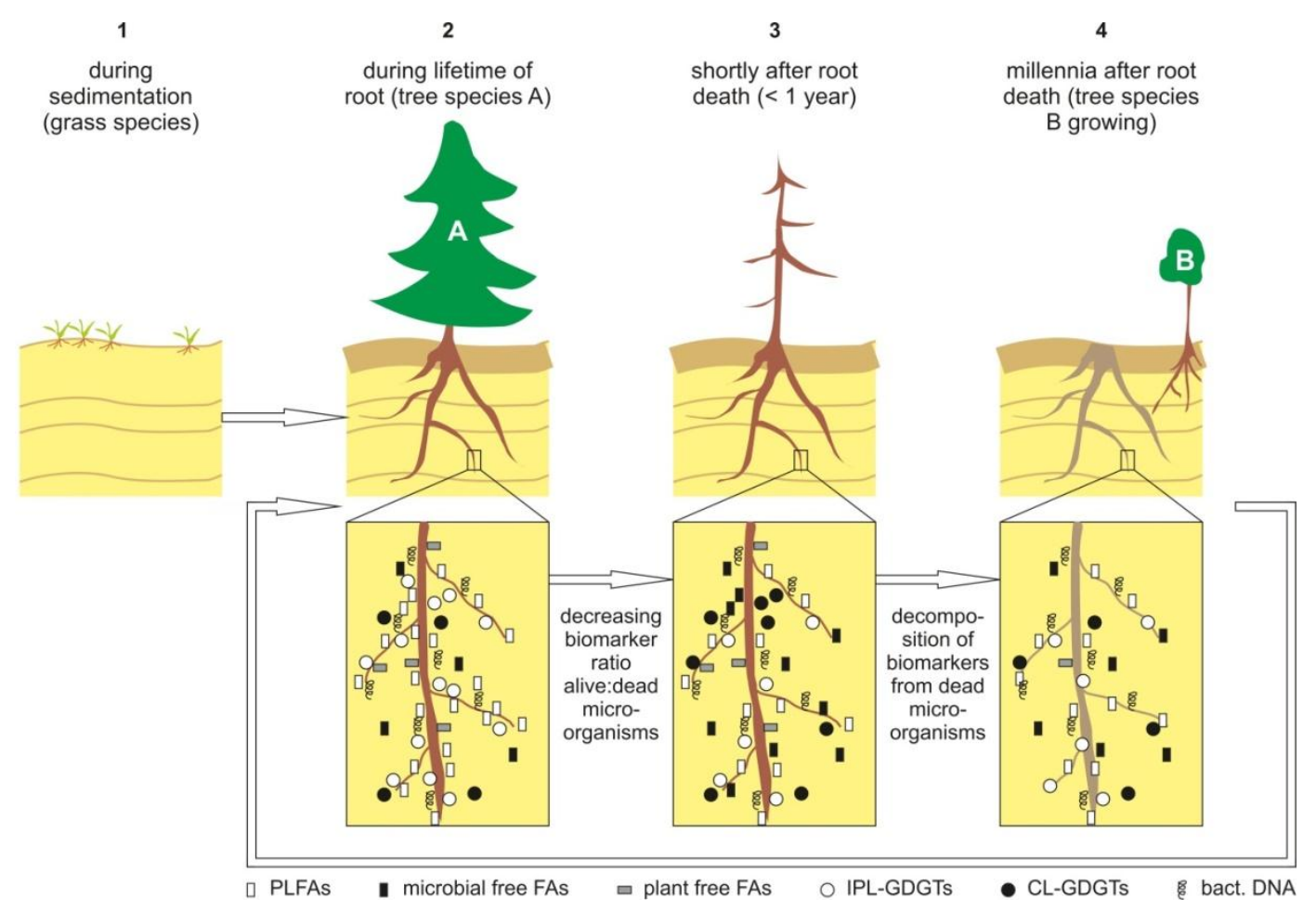

Figure 4.

Conceptual figure of root-related microorganism distribution and associated processes over time for vegetation growing on terrestrial sediments like e.g. loess or dune sands. 1) Synsedimentary situation with scarce vegetation cover consisting of grasses and herbaceous plants, with shallow roots. 2) Roots of tree vegetation A enter the deep subsoil, stimulating microbial life in the rhizosphere adjecent to roots. 3) After death of the root, the ratio living : dead microorganisms and thus the ratio intact polar : free/core lipids decreases. 4) Millenia after root death, biopores and/or rhizoliths remain. Quantities of signature molecules of dead microorganisms are reduced by degradation. Process rates decrease with time, but proceed continuously over long time spans. Living microorganisms feed on dead microbial remains as well as on plant remains and sedimentary organic matter. In the figure, roots of the next tree vegetation $(B)$ approach the ancient root systems, because the latter provide plant-available nutrients and old microorganism hotspots can be re-activated subsequently. New root effects may overprint old ones, e.g. if subsequent roots use old biopores. After phase 3, the cycle may thus continue with phase 2 and tree species $B$.

Our results disprove the traditional assumption of organic remains being solely incorporated during sediment deposition (Conte et al., 2003). This implies uncertainties for paleoenvironmental records in Quaternary terrestrial archives with allegedly high chronological resolution like loess-paleosol sequences. Horizontal transects from rhizoliths via rhizosphere towards root-free sediment at various study sites revealed the postsedimentary overprint of free FAs and core GDGTs (Huguet et al., 2012, 2013a; Gocke et al., 2014c), and similarly, PLFAs and intact polar GDGTs from microorganisms associated with living roots might have been incorporated (Fig. 4). The overprint of synsedimentary 
records and time-integrated character of free/core lipids are further enforced by the suspiciously similar depth diagrams of paleotemperature, reconstructed based on core and intact polar brGDGTs at Nussloch, which strongly disagree with Glacial conditions (Suppl. Fig. 5). This urges us to recommend the following cautions prior to sampling, i) at least $0.5 \mathrm{~m}$ of sediment should be removed from each side of the profile to avoid recent root effects, ii) the archive should be carefully regarded with respect to deep roots and iii) samples should be collected distant from visible root remains.

Further, ongoing OM incorporation and turnover by root-related microorganisms in deep subsoil will not necessarily entail the sequestration of additional C as recently postulated (Kell, 2012), but might rather cause net loss of considerable amounts of $C$ stored in paleosols (Marin-Spiotta et al., 2014) due to priming effects. Thus, the biogeochemical and ecological disequilibrium induced by fresh younger root and microbial biomass might even stimulate degradation of stabilized sedimentary OM (Fontaine et al., 2007). To answer this question, carbon stocks in the deep rhizosphere and in respective bulk soil/sediment have to be determined and opposed to each other. Generally, studies on the terrestrial C cycle as well as soil microbial studies should be extended to greater depths, including the soil parent material which has been largely neglected so far (Richter and Markewitz, 1995; Harper and Tibbett, 2013).

\section{Conclusions}

Signature molecules for both living and fossil microorganisms were found throughout a Central European $9.5 \mathrm{~m}$ thick soil-sediment profile, i.e. in the Holocene soil and in associated sedimentary deep subsoil of Pleistocene age. For the first time, we demonstrated significant correlations of microbial communities in sedimentary deep subsoil with frequencies of recent roots as well as fossil calcified roots, so-called rhizoliths, and root-derived biopores. Our unique multi-proxy approach revealed significant interrelationships of living microorganisms with recent root quantities, and of fossil microbial communities with frequencies of recent roots and ancient root remains. This indicated that i) the paleoenvironmental signal recorded in terrestrial sediments can be altered by postsedimentary rooting, and ii) roots may entail long-term maintenance of microbial life in deep subsoil. Plant roots entering deeper parts of the soil including the parent material up to several millenia after its deposition are thus an important source of carbon and nutrients, stimulating microbial life far beyond the lifetime of the root. The widespread occurrence of deep roots up to several meters below the topsoil not only 
at the current study site, but at several sites around the world, suggests that these root effects on deep subsoil microbial communities are not an exception.

\section{$\underline{\text { References }}$}

Agnelli, A., Ascher, J., Corti, G., Ceccherini, M.T., Pietramellara, G., Nannipieri, P., 2007. Purification and isotopic signatures $\left(\delta^{13} \mathrm{C}, \delta^{15} \mathrm{~N}, \Delta^{14} \mathrm{C}\right)$ of soil extracellular DNA. Biology and Fertility of Soils 44 , 353-361, doi: 10.1007/s00374-007-0213-y.

Antoine, P., Rousseau, D.D., Moine, O., Kunesch, S., Hatté, C., Lang, A., Tissoux, H., Zöller, L., 2009. Rapid and cyclic aeolian deposition during the Last Glacial in European loess: a high-resolution record from Nussloch, Germany. Quaternary Science Reviews 28, 2955-2973, doi: 10.1016/j.quascirev.2009.08.001.

Apostel, C., Dippold, M., Glaser, B., Kuzyakov, Y., 2013. Biochemical pathways of amino acids in soil: Assessment by position-specific labeling and ${ }^{13}$ C-PLFA analysis. Soil Biology \& Biochemistry 67 , 31-40, doi: 10.1016/j.soilbio.2013.08.005.

Ayari, A., Yang, H., Wiesenberg, G.L.B., Xie, S., 2013. Distribution of archaeal and bacterial tetraether membrane lipids in rhizosphere-root systems in soils and their implication for paleoclimate assessment. Geochemical Journal 47, 337-347, doi: 10.2343/geochemj.2.0249.

Bligh, E.G., Dyer, W.J., 1959. A rapid method of total lipid extration and purification. Canadian Journal of Biochemistry and Physiology 37, 911-917, doi: 10.1139/059-099.

Blume, E., Bischoff, M., Reichert, J.M., Moorman, T., Konopka, A., Turco, R.F., 2002. Surface and subsurface microbial biomass, community structure and metabolic activity as a function of soil depth and season. Applied Soil Ecology 20, 171-181, doi: 10.1016/S0929-1393(02)00025-2.

Breuker, A., Köweker, G., Blazejak, A., Schippers, A., 2001. The deep biosphere in terrestrial sediments in the Chesapeake Bay area, Virginia, USA. Frontiers in Microbiology 2, 156, doi: 10.3389/fmicb.2011.00156.

Brockman, F.J., Kieft, T.L., Fredrickson, J.K., Bjornstad, B.N., Li, S.W., Spangenburg, W., Long, P.E., 1992. Microbiology of Vadose Zone Paleosols in South-Central Washington State. Microbial Ecology 23, 279-301, doi: 10.1007/BF00164101.

Buckley, D.H., Graber, J.R., Schmidt, T.M., 1998. Phylogenetic analysis of nonthermophilic members of the kingdom Crenarchaeota and their diversity and abundance in soils. Applied and Environmental Microbiology 64, 4333-4339. 
Bundt, M., Widmer, F., Pesaro, M., Zeyer, J., Blaser, P., 2001. Preferential flow paths: biological 'hot spots' in soils. Soil Biology \& Biochemistry 33, 729-738, doi: 10.1016/S0038-0717(00)00218-2.

Canadell, J., Jackson, R.B., Ehleringer, J.R., Mooney, H.A., Sala, O.E., Schulze, E.D., 1996. Maximum rooting depth of vegetation types at the global scale. Oecologia 108, 583-595, doi: 10.1007/BF00329030.

Commission Internationale de l'Eclairage (CIE), 1931. Proceedings of the $8^{\text {th }}$ session of CIE. Cambridge University Press, UK.

Conte, M.H., Weber, J.C., Carlson, P.J., Flanagan, L.B., 2003. Molecular and carbon isotopic composition of leaf wax in vegetation and aerosols in a northern prairie ecosystem. Oecologia 135, 67-77, doi: 10.1007/s00442-002-1157-4.

Cranwell, P.A., 1981. Diagenesis of free and bound lipids in terrestrial detritus deposited in a lacustrine sediment. Organic Geochemistry 3, 79-89, doi: 10.1016/0146-6380(81)90002-4.

Degelmann, D., Kolb, S., Dumont, M., Murrell, J.C., Drake, H.L., 2009. Enterobacteriaceae facilitate the anaerobic degradation of glucose by a forest soil. FEMS Microbiological Ecology 68, 312-319, doi: 10.1111/j.1574-6941.2009.00681.x.

Dippold, M.A., Kuzyakov, Y., 2015. Direct incorporation of fatty acids into microbial phospholipids in soils: Position-specific labeling tells the story. Geochimica et Cosmochimica Acta 174, 211-221, doi: 10.1016/j.gca.2015.10.032.

Egert, M., Friedrich, M.W., 2003. Formation of pseudoterminal restriction fragments, a PCR-related bias affecting terminal restriction fragment length polymorphism analysis of microbial community structure. Applied and Environmental Microbiology 69, 2555-2562, doi: 10.1128/AEM.69.5.25552562.2003.

Eglinton, G., Gonzalez, A.G., Hamilton, R.J., Raphael, R.A., 1962. Hydrocarbon constituents of the wax coatings of plant leaves: a taxonomic survey. Phytochemistry 1, 89-102, doi: 10.1016/S00319422(00)88006-1.

Fernandes, M.F., Saxena, J., Dick, R.P., 2013. Comparison of Whole-Cell Fatty Acid (MIDI) or Phospholipid Fatty Acid (PLFA) Extractants as Biomarkers to Profile Soil Microbial Communities. Microbial Ecology 66, 145-157, doi: 10.1007/s00248-013-0195-2.

Fierer, N., Schimel, J.P., Holden, P.A., 2003. Variations in microbial community composition through two soil depth profiles. Soil Biology \& Biochemistry 35, 167-176, doi: 10.1016/S00380717(02)00251-1. 
Fisher, M.J., Rao, I.M., Ayarza, M.A., Lascano, C.E., Sanz, J.I., Thomas, R.J., Vera, R.R., 1994. Carbon storage by introduced deep-rooted grasses in the South American savannas. Nature 371, 236-238, doi: 10.1038/371236a0.

Fontaine, S., Barot, S., Barré, P., Bdioui, N., Mary, B., Rumpel, C., 2007. Stability of organic carbon in deep soil layers controlled by fresh carbon supply. Nature 450, 277-280, doi: 10.1038/nature06275.

Gocke, M., Pustovoytov, K., Kühn, P., Wiesenberg, G.L.B., Löscher, M., Kuzyakov, Y., 2011.

Carbonate rhizoliths in loess and their implications for paleoenvironmental reconstruction revealed by isotopic composition: $\delta^{13} \mathrm{C},{ }^{14} \mathrm{C}$. Chemical Geology $283,251-260$, doi:

10.1016/j.chemgeo.2011.01.022.

Gocke, M., Kuzyakov, Y., Wiesenberg, G.L.B., 2013. Differentiation of plant derived organic matter in soil, loess and rhizoliths based on $n$-alkane molecular proxies. Biogeochemistry 112, 23-40, doi: 10.1007/s10533-011-9659-y.

Gocke, M., Gulyás, S., Hambach, U., Jovanović, M., Kovács, G., Marković, S.B., Wiesenberg, G.L.B., 2014a. Biopores and root features as new tools for improving paleoecological understanding of terrestrial sediment-paleosol sequences. Palaeogeography Palaeoclimatology Palaeoecology 394, 42-58, doi: 10.1016/j.palaeo.2013.11.010.

Gocke, M., Hambach, U., Eckmeier, E., Schwark, L., Zöller, L., Fuchs, M., Wiesenberg, G.L.B., 2014b. Introducing an improved multi-proxy approach for paleoenvironmental reconstruction of loesspaleosol archives applied on the Late Pleistocene Nussloch sequence (SW Germany). Palaeogeography Palaeoclimatology Palaeoecology 410, 300-315, doi: 10.1016/j.palaeo.2014.06.006.

Gocke, M., Peth, S., Wiesenberg, G.L.B., 2014c. Lateral and depth variation of loess organic matter overprint related to rhizoliths - Revealed by lipid molecular proxies and X-ray tomography. Catena 112, 72-85, doi: 10.1016/j.catena.2012.11.011

Gocke, M.I., Kessler, F., van Mourik, J.M., Jansen, B., Wiesenberg, G.L.B., 2015. Paleosols can promote root growth of the recent vegetation - a case study from the sandy soil-sediment sequence Rakt, the Netherlands. SOILD 2, 1273-1308, doi: 10.5194/soild-2-1273-2015.

Hamberger, A., Horn, M.A., Dumont, M.G., Murrell, J.C., Drake, H.L., 2008. Anaerobic consumers of monosaccharides in a moderately acidic fen. Applied and Environmental Microbiology 74, 31123120, doi: 10.1128/AEM.00193-08. 
Hansel, C.M., Fendorf, S., Jardine, P.M., Francis, C.A., 2008. Changes in Bacterial and Archaeal Community Structure and Functional Diversity along a Geochemically Variable Soil Profile. Applied and Environmental Microbiology 74, 1620-1633, doi: 10.1128/AEM.01787-07.

Harper, R.J., Tibbett, M., 2013. The hidden organic carbon in deep mineral soils. Plant and Soil 368, 641-648, doi: 10.1007/s11104-013-1600-9.

Harvey, H.R., Fallon, R.D., Patton, J.S., 1986. The effect of organic matter and oxygen on the degradation of bacterial membrane lipids in marine sediments. Geochimica et Cosmochimica Acta 50, 795-804, doi: 10.1016/0016-7037(86)90355-8.

Harwood, J L., Russell, N.J., 1984. Lipids in plants and microbes. George Allen \& Unwin, London.

Helgason, B.L., Konschuh, H.J., Bedard-Haughn, A., VandenBygaart, A.J., 2014. Microbial distribution in an eroded landscape: Buried A horizons support abundant and unique communities. Agriculture, Ecosystems \& Environment 196, 94-102, doi: 10.1016/j.agee.2014.06.029.

Holden, P.A., Fierer, N., 2005. Microbial Processes in the Vadose Zone. Vadose Zone Journal 4, 1-21, doi: $10.2113 / 4.1 .1$

Huguet, A., Wiesenberg, G.L.B., Gocke, M., Fosse, C., Derenne, S., 2012. Branched tetraether membrane lipids associated with rhizoliths in loess: Rhizomicrobial overprinting of initial biomarker record. Organic Geochemistry 43, 12-19, doi: 10.1016/j.orggeochem.2011.11.006.

Huguet, A., Gocke, M., Derenne, S., Fosse, C., Wiesenberg, G.L.B., 2013a. Root-associated branched tetraether source microorganisms may reduce estimated paleotemperatures in subsoil. Chemical Geology 356, 1-10, doi: 10.1016/j.chemgeo.2013.07.017.

Huguet, A., Fosse, C., Laggoun-Défarge, F., Delarue, F., Derenne, S., 2013b. Effects of a short-term experimental microclimate warming on the abundance and distribution of branched GDGTs in a French peatland. Geochimica et Cosmochimica Acta 105, 294-315, doi: 10.1016/j.gca.2012.11.037.

Ingalls, A.E., Huguet, C., Truxal, L.T., 2012. Distribution of Intact and Core Membrane Lipids of Archaeal Glycerol Dialkyl Glycerol Tetraethers among Size-Fractionated Particulate Organic Matter in Hood Canal, Puget Sound. Applied and Environmental Microbiology 78, 1480-1490, doi: 10.1128/AEM.07016-11.

IUSS Working Group WRB, 2014. World Reference Base for Soil Resources 2014. International soil classification system for naming soils and creating legends for soil maps. World Soil Resources Reports No. 106. FAO, Rome. 
Janssen, P.H., 2006. Identifying the Dominant Soil Bacterial Taxa in Libraries of 16S rRNA and 16S rRNA Genes. Applied and Environmental Microbiology 72, 1719-1728, doi: 10.1128/AEM.72.3.1719-1728.2006.

Johnson, W.C., 2014. Carbon cycle: Sequestration in buried soils. Nature Geoscience 7, 398-399, doi: $10.1038 /$ ngeo2172.

Kautz, T., Amelung, W., Ewert, F., Gaiser, T., Horn, R., Jahn, R., Javaux, M., Kemna, A., Kuzyakov, Y., Munch, J.C., Pätzold, S., Peth, S., Scherer, H.W., Schloter, M., Schneider, H., Vanderborght, J., Vetterlein, D., Walter, A., Wiesenberg, G.L.B., Köpke, U., 2013. Nutrient acquisition from arable subsoils in temperate climates: A review. Soil Biology \& Biochemistry 57, 1003-1022, doi: 10.1016/j.soilbio.2012.09.014.

Kell, D.B., 2012. Large-scale sequestration of atmospheric carbon via plant roots in natural and agricultural ecosystems: why and how. Philosophical Transactions of The Royal Society B Biological Sciences 367, 1589-1597, doi: 10.1098/rstb.2011.0244.

Kindler, R., Miltner, A., Thullner, M., Richnow, H.H., Kästner, M., 2009. Fate of bacterial biomass derived fatty acids in soil and their contribution to soil organic matter. Organic Geochemistry 40, 29-37, doi: 10.1016/j.orggeochem.2008.09.005.

Klappa, C.F., 1980. Rhizoliths in terrestrial carbonates: classification, recognition, genesis and significance. Sedimentology 27, 613-629, doi: 10.1111/j.1365-3091.1980.tb01651.x.

Kolattukudy, P.E., 1984. Biochemistry and function of cutin and suberin. Canadian Journal of Botany 62, 2918-2933, doi: 10.1139/b84-391.

Kolattukudy, P.E., Croteau, R., Buckner, J.S., 1976. Biochemistry of plant waxes. In: Kollatukudy, P.E. (Ed.), Chemistry and Biochemistry of Natural Waxes. Elsevier, Amsterdam, pp. 290-347.

Kramer, C., Gleixner, G., 2006. Variable use of plant- and soil-derived carbon by microorganisms in agricultural soils. Soil Biology \& Biochemistry 38, 3267-3278, doi: 10.1016/j.soilbio.2006.04.006.

Lengger, S.K., Kraaij, M., Tjallingii, R., Baas, M., Stuut, J.B., Hopmans, E.C., Sinninghe Damsté, J.S., Schouten, S., 2013. Differential degradation of intact polar and core glycerol dialkyl glycerol tetraether lipids upon post-depositional oxidation. Organic Geochemistry 65, 83-93, doi: 10.1016/j.orggeochem.2013.10.004.

Lichtfouse, É., Berthier, G., Houot, S., Barriuso, E., Bergheaud, V., Vallaeys, T., 1995. Stable carbon isotope evidence for the microbial origin of $\mathrm{C}_{14}-\mathrm{C}_{18} \mathrm{n}$-alkanoic acids in soils. Organic Geochemistry 23, 849-852, doi: 10.1016/0146-6380(95)80006-D. 
Liu, W., Yang, H., Ning, Y., An, Z., 2007. Contribution of inherent organic carbon to the bulk $\delta^{13} \mathrm{C}$ signal in loess deposits from the arid western Chinese Loess Plateau. Organic Geochemistry 38, 1571-1579, doi: 10.1016/j.orggeochem.2007.05.004.

Maher, B.A., 2011. The magnetic properties of Quaternary aeolian dusts and sediments, and their palaeoclimatic significance. Aeolian Research 3, 87-144, doi: 10.1016/j.aeolia.2011.01.005.

Marin-Spiotta, E., Chaopricha, N.T., Plante, A.F., Diefendorf, A.F., Mueller, C.W., Grandy, A.S., Mason, J.A., 2014. Long-term stabilization of deep soil carbon by fire and burial during early Holocene climate change. Nature Geoscience 7, 428-432, doi: 10.1038/ngeo2169.

McKirdy, D.M., Thorpe, C.S., Haynes, D.E., Grice, K., Krull, E.S., Halverson, G.P., Webster, L.J., 2009. The biogeochemical evolution of the Coorong during the mid-to-late Holocene: An elemental, isotopic and biomarker perspective. Organic Geochemistry 41, 96-110, doi: 10.1016/j.orggeochem.2009.07.010.

Messing, J., 1983. New M13 vectors for cloning. Methods in Enzymology 101, 20-78, doi: 10.1016/0076-6879(83)01005-8.

Peterse, F., Graeme, W.N., Schouten, S., Sinninghe Damsté, J.S., 2010. Influence of soil pH on the abundance and distribution of core and intact polar lipid-derived branched GDGTs in soil. Organic Geochemistry 41, 1171-1175, doi: 10.1016/j.orggeochem.2010.07.004.

Reiffarth, D.G., Petticrew, E.L., Owens, P.N., Lobb, D.A., 2016. Sources of variability in fatty acid (FA) biomarkers in the application of compound-specific stable isotopes (CSSIs) to soil and sediment fingerprinting and tracing: A review. Sciene of the Total Environment 565, 8-27, doi: 10.1016/j.scitotenv.2016.04.137.

Richter, D D., Markewitz, D., 1995. How deep is soil? BioScience 45, 600-609, doi: 10.2307/1312764.

Schellenberger, S., Kolb, S., Drake, H.L., 2010. Metabolic responses of novel cellulolytic and saccharolytic agricultural soil Bacteria to oxygen. Environmental Microbiology 12, 845-861, doi: 10.1111/j.1462-2920.2009.02128.x.

Schouten, S., Middelburg, J.J., Hopmans, E.C., Sinninghe Damsté, J.S., 2010. Fossilization and degradation of intact polar lipids in deep subsurface sediments: a theoretical approach. Geochimica et Cosmochimica Acta 74, 3806-3814, doi: 10.1016/j.gca.2010.03.029.

Schouten, S., Hopmans, E.C., Sinninghe Damsté, J.S., 2013. The organic geochemistry of glycerol dialkyl glycerol tetraether lipids: A review. Organic Geochemistry 54, 19-61, doi: 10.1016/j.orggeochem.2012.09.006. 
Sinninghe Damsté, J.S., Rijpstra, W.I.C., Hopmans, E.C., Weijers, J.W.H., Foesel, B.U., Overmann, J., Dedysh, S.N., 2011. 13,16-Dimethyl Octacosanedioic Acid (iso-Diabolic Acid), a Common Membrane-Spanning Lipid of Acidobacteria Subdivisions 1 and 3. Applied and Environmental Microbiology 77, 4147-4154, doi: 10.1128/AEM.00466-11.

Sinninghe Damsté, J.S., Rijpstra, W.I.C., Hopmans, E.C., Foesel, B.U., Wüst, P.K., Overmann, J., Tank, M., Bryant, D.A., Dunfield, P.F., Houghton, K., Stott, M.B., 2014. Ether- and Ester-Bound isoDiabolic Acid and Other Lipids in Members of Acidobacteria Subdivision 4. Applied and Environmental Microbiology 80, 5207-5218, doi: 10.1128/AEM.01066-14.

Stone, M.M., DeForest, J.L., Plante, A.F., 2014. Changes in extracellular enzyme activity and microbial community structure with soil depth at the Luquillo Critical Zone Observatory. Soil Biology \& Biochemistry 75, 237-247, doi: 10.1016/j.soilbio.2014.04.017.

Takano, Y., Chikaraishi, Y., Ogawa, N.O., Nomaki, H., Morono, Y., Inagaki, F., Kitazato, H., Hinrichs, K.-U., Ohkouchi, N., 2010. Sedimentary membrane lipids recycled by deep-see benthic archaea. Nature Geoscience 3, 858-861, doi: 10.1038/ngeo983.

Wang, Y., Li, Y., Ye, X., Chu, Y., Wang, X., 2010. Profile storage of organic/inorganic carbon in soil: From forest to desert. Science of the Total Environment 408, 1925-1931, doi: 10.1016/j.scitotenv.2010.01.015.

Wang, X., Lu, H., Xu, H., Deng, C., Cheng, T., Wang, X., 2006. Magnetic properties of loess deposits on the northeastern Qinghai-Tibetan Plateau: palaeoclimatic implications for the Late Pleistocene. Geophysical Journal International 167, 1138-1147, doi: 10.1111/j.1365-246X.2006.03007.x.

Weijers, J.W.H., Wiesenberg, G.L.B., Bol, R., Hopmans, E.C., Pancost, R.D., 2010. Carbon isotopic composition of branched tetraether membrane lipids in soils suggest a rapid turnover and a heterotrophic life style of their source organism(s). Biogeosciences 7, 2959-2973, doi: 10.5194/bg7-2959-2010.

Whitman, W.B., Coleman, D.C., Wiebe, W.J., 1998: Prokaryotes: The unseen majority. Proceedings of the National Academy of Sciences of the United States of America 95, 6578-6583, doi: 10.1073/pnas.95.12.6578.

Wiesenberg, G.L.B., Gocke, M.I., 2015. Analysis of lipids and polycyclic aromatic hydrocarbons as indicators of past and present (micro)biological activity. In: McGenity, T.J., Timmis, K.N., Nogales, B. (Eds.), Hydrocarbon and Lipid Microbiology: Cultivation. Springer Protocol Handbooks. Springer, Berlin Heidelberg, pp. 1-31, doi: 10.1007/8623_2015_157. 
Woltering, M., Atahan, P., Grice, K., Heijnis, H., Taffs, K., Dodson, J., 2014. Glacial and Holocene terrestrial temperature variability in subtropical east Australia as inferred from branched GDGT distributions in a sediment core from Lake McKenzie. Quaternary Research 82, 132-145, doi: org/10.1016/j.yqres.2014.02.005.

Yang, H., Pancost, R.D., Dang, X., Zhou, X., Evershed, R.P., Xiao, G., Tang, C., Gao, L., Guo, Z., Xie, S., 2014. Correlations between microbial tetraether lipids and environmental variables in Chinese soils: Optimizing the paleo-reconstructions in semid-arid and arid regions. Geochimica et Cosmochimica Acta 126, 46-69, doi: 10.1016/j.gca.2013.10.041.

Zelles, L., 1999. Fatty acid patterns of phospholipids and lipopolysaccharides in the characterisation of microbial communities in soil: a review. Biology and Fertility of Soils 29, 111-129, doi: $10.1007 / \mathrm{s} 003740050533$

\section{Acknowledgments}

The study was funded by the German Research Foundation (grant number DFG-WI 2810/10-1) and by the Swiss National Science Foundation (grant number 153631). The authors further thank LabEx Matisse for funding, and acknowledge financal support from the French-German PHC/ DAAD PROCOPE program. HeidelbergCement AG (Heidelberg, Germany) enabled sampling in their quarries, assisted by M. Löscher (Leimen, Germany). Several MSc and PhD students as well as technicians supported DNA (S. Hetz, R. Mertel, O. Schmidt, A. Stacheter, A. Wieczorek [University of Bayreuth, Germany]) and GDGT analyses (C. Anquetil [UPMC Paris, France], C. Fosse [Chimie Paris Tech, France], C.-L. Müller [University of Bayreuth, Germany]). Access to microbiology laboratory was provided by H. Drake (University of Bayreuth, Germany).

\section{Author contributions}

M.I.G. and G.L.B.W. initiated the study, conducted field work and data compilation as well as interpretation. M.I.G. prepared the first draft of the manuscript and performed analyses and evaluation of free FAs, PLFAs and DNA. A.H. and S.D. conducted GDGT analyses and evaluation. S.K. provided equipment for DNA analyses and introduced M.I.G. to the respective methods. M.A.D. contributed to PLFA analysis and conducted statistical evaluation of the data set. All authors actively participated in the discussion and manuscript improvement. 


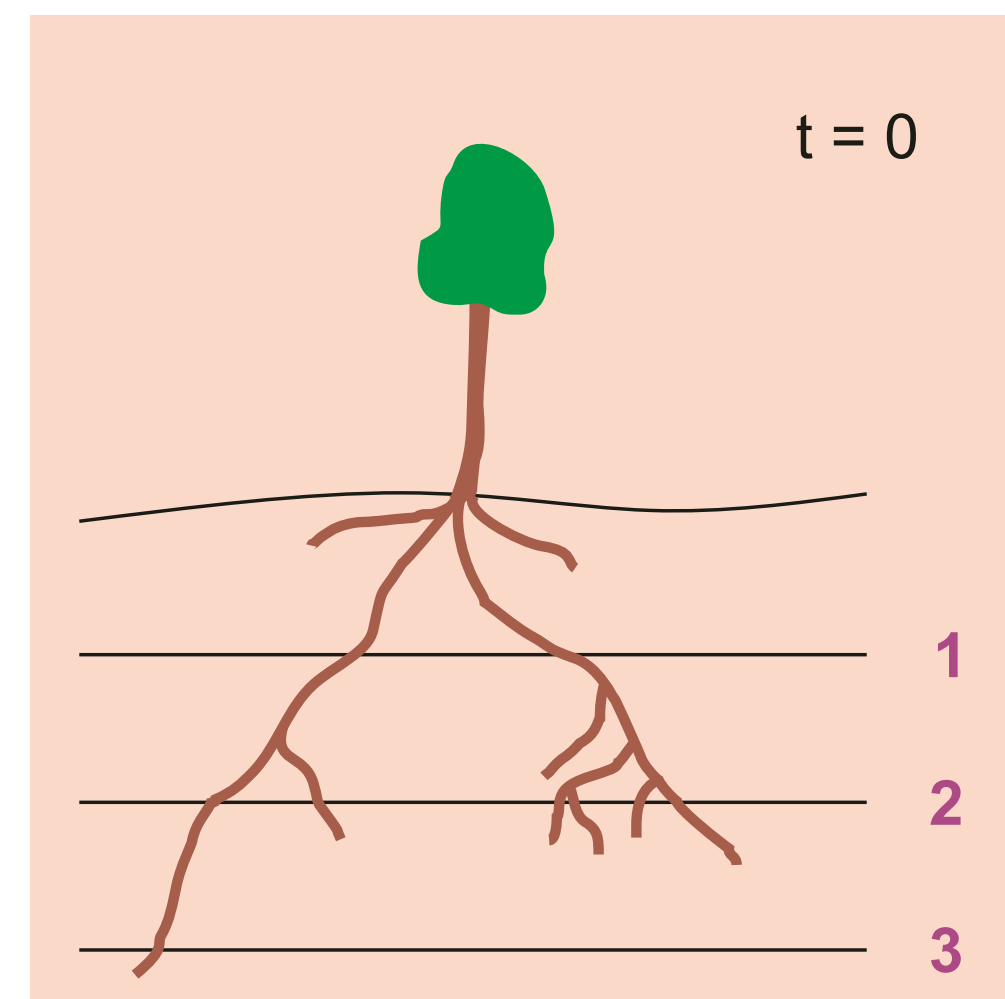

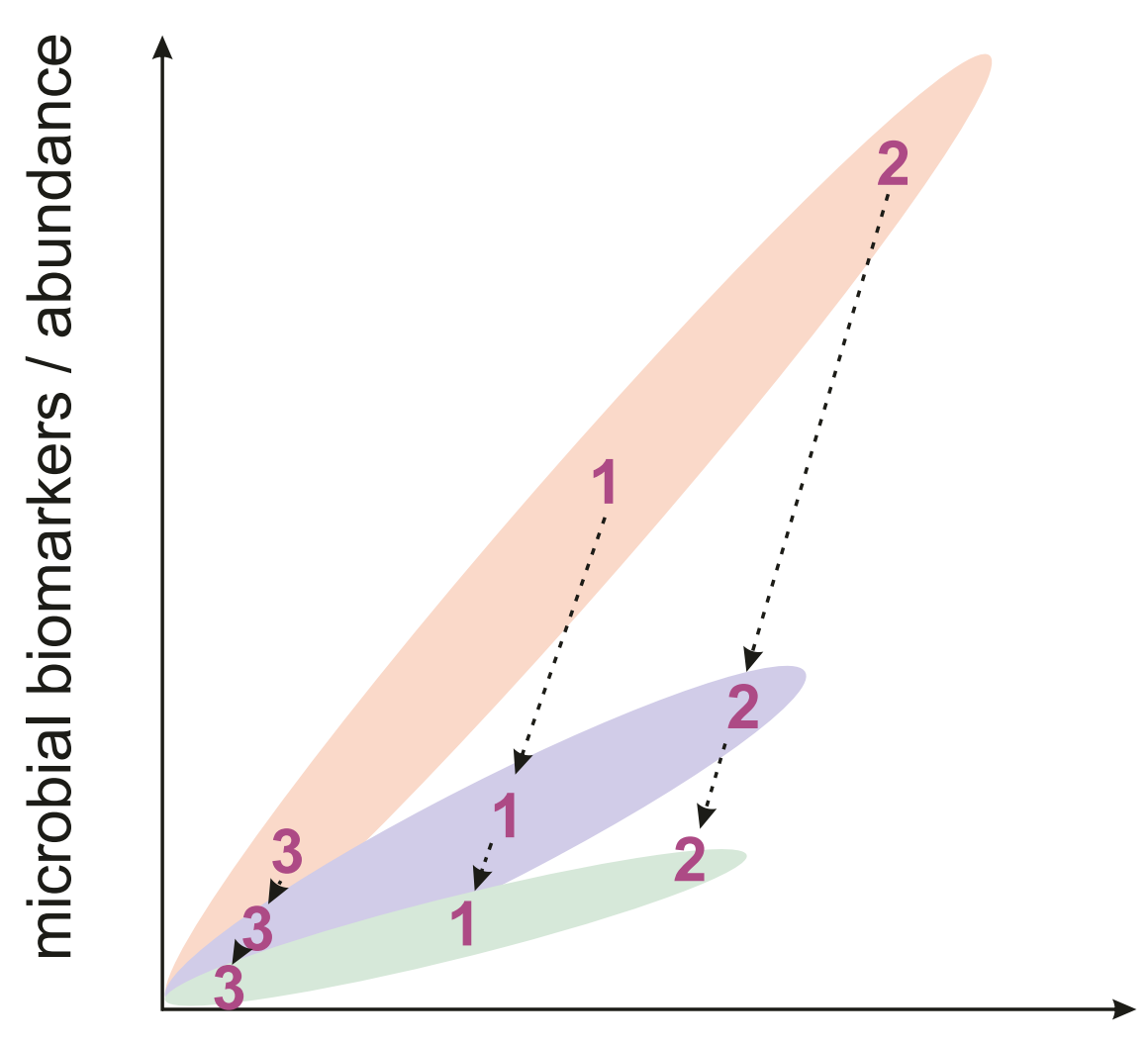

root (remains) abundance

aging

$1,2,3$ depth interval with different root feature frequency

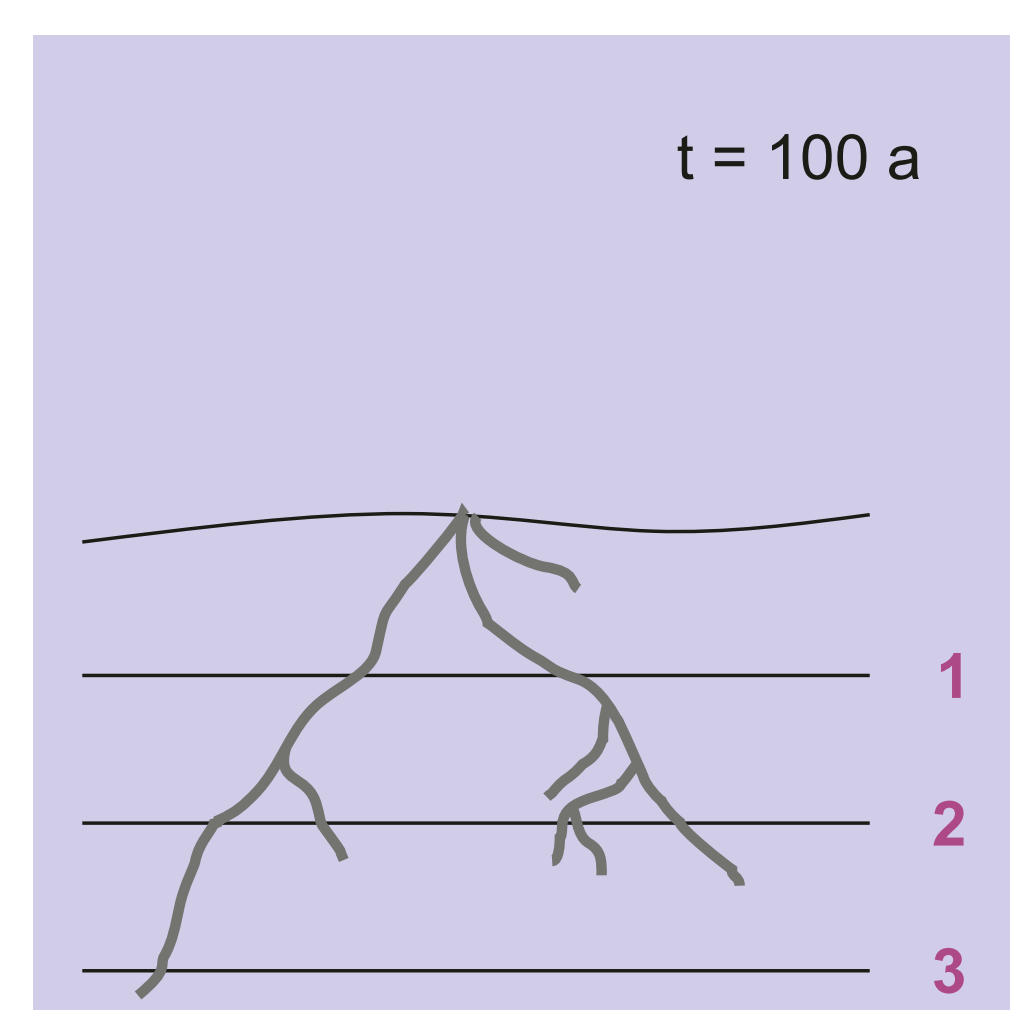

$t=5,000 a$

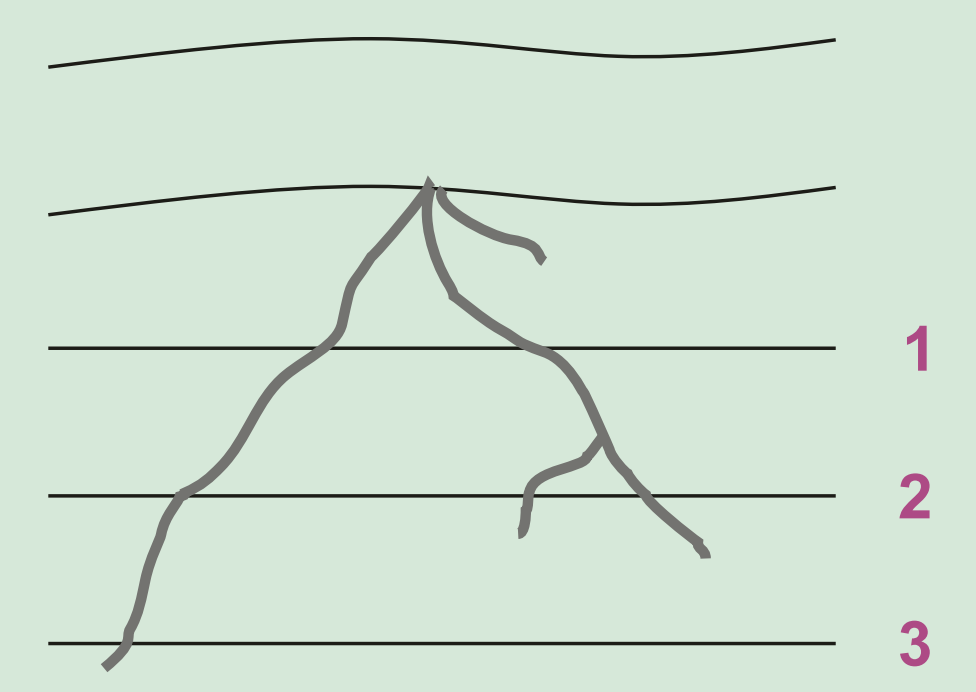

